\title{
Biodegradable Polymers for Gene Delivery
}

\author{
T. J. Thomas ${ }^{1,2, * \mathbb{C}}$, Heidar-Ali Tajmir-Riahi ${ }^{2}$ and C. K. S. Pillai ${ }^{3,+}$
}

1 Department of Medicine, Rutgers Robert Wood Johnson Medical School, KTL N102, 675 Hoes Lane, Piscataway, NJ 08854, USA

2 Rutgers Cancer Institute of New Jersey, New Brunswick, NJ 08901, USA; tajmirri@uqtr.ca

3 Department of Chemistry-Biochemistry-Physics, University of Québec in Trois-Rivières, C. P. 500, Trois-Rivières, QC G9A 5H7, Canada; ckspillai@gmail.com

* Correspondence: thomastj@rwjms.rutgers.edu

+ Retired from National Institute for Interdisciplinary Science and Technology, CSIR, Thiruvananthapuram 695 019, India. Current address: Amrutham, TC 52/3772, Karumom, Thiruvananthapuram 695002, India.

Received: 12 August 2019; Accepted: 8 October 2019; Published: 17 October 2019

\begin{abstract}
The cellular transport process of DNA is hampered by cell membrane barriers, and hence, a delivery vehicle is essential for realizing the potential benefits of gene therapy to combat a variety of genetic diseases. Virus-based vehicles are effective, although immunogenicity, toxicity and cancer formation are among the major limitations of this approach. Cationic polymers, such as polyethyleneimine are capable of condensing DNA to nanoparticles and facilitate gene delivery. Lack of biodegradation of polymeric gene delivery vehicles poses significant toxicity because of the accumulation of polymers in the tissue. Many attempts have been made to develop biodegradable polymers for gene delivery by modifying existing polymers and/or using natural biodegradable polymers. This review summarizes mechanistic aspects of gene delivery and the development of biodegradable polymers for gene delivery.
\end{abstract}

Keywords: gene delivery; biodegradable polymers; DNA condensation; DNA nanoparticles; polyethyleneimine; poly-L-lysine; chitosan; pullulan; dextran; hyaluronic acid; gene delivery mechanisms

\section{Introduction}

Gene therapy approaches are under development to treat diseases that arise from genetic abnormalities [1-5]. Successful gene therapy requires the efficient delivery of genetic material through the cell membrane into target sites in order to treat these diseases. Transport of DNA through the cell membrane is an inefficient process, and the mechanism(s) by which this process occurs is not clear [6-12]. There are two types of delivery vehicles used in gene therapy, viral and non-viral vectors, both of which present specific advantages and disadvantages [13-16]. Currently employed viral vectors include retroviruses, adenoviruses, and adeno-associated viruses, and each one of them has its own unique advantages [17-21]. Viral vectors are highly effective in achieving high efficiency for both gene delivery and expression, and exhibit stable long-term expression of a foreign gene when the recombinant DNA is integrated into the chromosomal DNA [22-24]. Major limitations of virally mediated gene delivery include limited DNA carrying capacity, toxicity, potential replication, immunogenicity, cancer formation and high cost. Non-viral gene delivery vehicles are being developed to overcome the deficiencies of viral vectors [25-30].

The concept of non-viral gene transfer can be described simply as the use of carriers other than virus which: (a) Mimics viral infection processes; (b) condenses DNA; (c) protects DNA from degradation; (d) promote cellular uptake and nuclear delivery; and (e) are non-immunogenic and non-cytotoxic $[31,32]$. Lipids, polymers and peptides are some of the non-viral vectors that have 
been developed in the past three decades [33-37]. These polymers interact with nucleic acids and form nanoparticles to facilitate gene delivery, with the advantages of low toxicity, cost-effectiveness, ease of production, and versatility for different applications [38-44]. Amongst the various non-viral vectors developed, cationic polymers have been considered as the most promising candidates with enormous potentials and advantages in comparison to their counterparts owing to their unique characteristics of forming polyelectrolyte complexes with genes and the ability to protect DNA from various enzymes $[45,46]$. The polymer vectors used in gene delivery should meet several requirements, including: (i) The ability to protect the genetic material from enzymatic degradation, (ii) provide long lifetime in the blood circulation, (iii) direct the genetic material to specific cellular/tissue sites, (iv) degrade and eliminate from the human body without exerting undesirable side effects, (v) the ability to enter the target cell, crossing the cell membrane and transiting through the cytosol and/or crossing the nuclear membrane to release the genetic material at the desired point of action [47].

Both synthetic and natural polymers have been used for gene delivery, and several reviews are available in the literature [48-52]. However, these reviews were published approximately a decade ago, and hence, we prepared this review to outline earlier research in this area and to describe developments during the past decade, especially in the area of biodegradable polymers for gene delivery applications.

\section{DNA Condensation to Nanoparticles for Gene Delivery}

An essential requirement of DNA entry to cells is the condensation of DNA, a process by which long DNA chains are collapsed into nanoparticles of 50-200 nm diameter $[8,9,26,27,40-42,53-58]$. The interaction of multivalent cationic ligands with DNA results in the condensation of DNA to nanoparticles and facilitates DNA transport through the cell membrane $[9,26]$. An example of such nanoparticle formation with the natural polyamines, spermidine $\left(\mathrm{H}_{2} \mathrm{~N}\left(\mathrm{CH}_{2}\right)_{3} \mathrm{NH}\left(\mathrm{CH}_{2}\right)_{4} \mathrm{NH}_{2}\right)$ and spermine $\left(\mathrm{H}_{2} \mathrm{~N}\left(\mathrm{CH}_{2}\right)_{3} \mathrm{NH}\left(\mathrm{CH}_{2}\right)_{4} \mathrm{NH}\left(\mathrm{CH}_{2}\right)_{3} \mathrm{NH}_{2}\right)$, and synthetic polyamines are illustrated in Figure 1 .
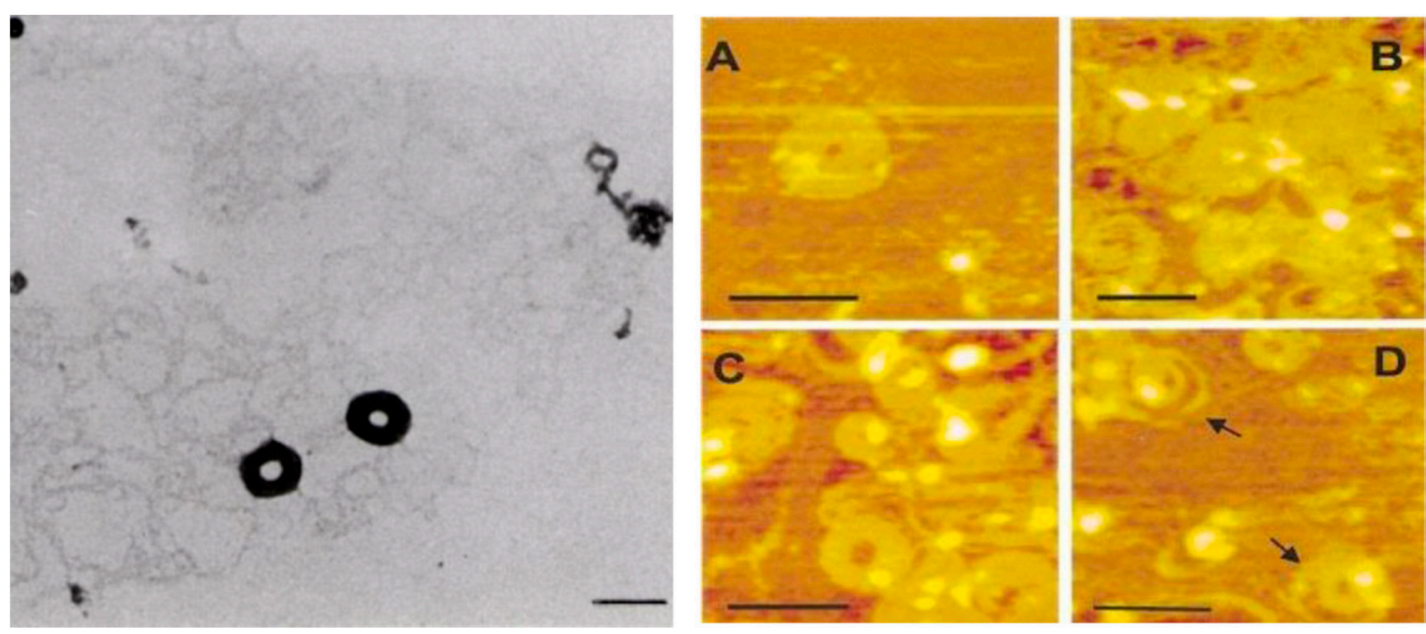

Figure 1. Electron micrograph of DNA treated with $200 \mu \mathrm{M}$ of spermidine (Left). Scale bar is $100 \mathrm{~nm}$. Scanning force microscopy images showing the toroid structures of pGL3 plasmid DNA formed by incubation with polyamines (Right). (A) $25 \mu \mathrm{M}$ spermine; (B) $5 \mu \mathrm{M}$ of pentamine (3-3-3-3, $\left.\mathrm{H}_{2} \mathrm{~N}\left(\mathrm{CH}_{2}\right)_{3} \mathrm{NH}\left(\mathrm{CH}_{2}\right)_{3} \mathrm{NH}\left(\mathrm{CH}_{2}\right)_{3} \mathrm{NH}\left(\mathrm{CH}_{2}\right)_{3} \mathrm{NH}_{2}\right) ;$ (C) $2 \mu \mathrm{M}$ of hexamine (3-4-3-4-3, $\left.\mathrm{H}_{2} \mathrm{~N}\left(\mathrm{CH}_{2}\right)_{3} \mathrm{NH}\left(\mathrm{CH}_{2}\right)_{4} \mathrm{NH}\left(\mathrm{CH}_{2}\right)_{3} \mathrm{NH}\left(\mathrm{CH}_{2}\right)_{4} \mathrm{NH}_{2}\left(\mathrm{CH}_{2}\right)_{3} \mathrm{NH}_{2}\right)$. The numbering system in these synthetic polyamines is the number of $-\mathrm{CH}_{2}$ - groups between amino and imino groups. (D) Scale bar is $200 \mathrm{~nm}$. Adapted with permission from Reference [41].

The natural polyamines have been extensively studied for their ability to collapse DNA to nanoparticles [59-63]. The energetic force governing the condensation of DNA is the differential between attractive and repulsive forces between DNA strands. By combining single-molecule magnetic tweezers and osmotic stress on DNA assemblies, Todd et al. separated attractive and repulsive 
components of the total intermolecular interaction between multivalent cation condensed DNA strands [64]. Based on measurements of different cations, including cobalt hexamine $\left(\mathrm{Co}\left(\mathrm{NH}_{3}\right)_{6}{ }^{3+}\right)$, natural polyamines, synthetic pentamine and hexamine, Todd et al. identified two invariant properties of multivalent cation-mediated DNA interactions: Repulsive forces decay exponentially with a $2.3 \pm 0.1 \AA$ characteristic decay length, and the attractive component of the free energy was always $2.3 \pm 0.2$ times larger than the repulsive component of the free energy at force-balance equilibrium, irrespective of the nature of the cation [64]. The experimental measurements indicated the importance of electrostatic interactions, consistent with theories for Debye-Hückel interactions between helical line charges and with the order-parameter formalism for hydration forces $[26,60]$. However, ionic, structural and temperature effects were evident in the interaction of polyamines with DNA [40-42,65-68].

Thomas et al. tested the ability of a series of polyamine analogues for transporting a triplex DNA forming oligonucleotide in MCF-7 breast cancer cells and found that hexamine analogues of spermine were excellent candidates for oligonucleotide delivery [69]. Structurally modified oligoamines were also developed as nanocarrier gene delivery agents [70]. Polyamine-based delivery vehicles interfered with the polyamine metabolic pathway and depleted the level of natural polyamines [59,69,70]. DNA condensation by amino acids and protamine was considered to be a model for DNA packaging in the sperm [26,71]. Arginine rich polyplexes were also studied for gene delivery [72].

\section{Mechanistic Aspects of Gene Delivery by Polymeric Vehicles}

The cell membrane is a major barrier for the specific and efficient delivery of the nucleic acid cargo by non-viral delivery vehicles. Due to their large size and anionic nature, DNA and siRNA cannot diffuse across the cell membrane and require active internalization by endocytosis $[9,26,27,73,74]$. Supramolecular chemistry aids in the organization of large DNA molecules to highly organized nanoparticles of approximately 50-200 $\mathrm{nm}$ diameter toroids or spheres by electrostatic and/or other forms of interactions with nanocarriers, such as cationic polymers $[9,26,40]$. The DNA nanoparticles appear to be in a liquid crystalline state, with charge inversion conferring positive charges on their surface, and facilitating endocytosis through negatively charged proteoglycans on the cell surface $[61,66,75,76]$. A schematic model for the cellular uptake mechanism is given in Figure 2.

The endocytic pathway is mainly divided into four different types: (i) Phagocytosis, (ii) clathrinmediated endocytosis, (iii) caveolae-mediated endocytosis, and (iv) macro- and micro-pinocytosis [9,12,56,77]. However, other types of processes, such as flotillin-dependent endocytosis, circular dorsal ruffles, and etosis have also been described in the literature [12,77,78]. Phagocytosis is predominant in macrophages, monocytes, neutrophils and dendritic cells and particles with a diameter of 2-3 $\mu \mathrm{m}$ diameter. The clathrin dependent endocytosis pathway is a receptor-dependent pathway, mediated by clathrin and requires GTPase dynamin. The assembly of clathrins occurs in the polyhedral lattice on the cytosolic surface of the cell membrane, which helps to deform the membrane into a coated pit with 100-150 nm size for invagination of the cargo containing the genetic material [79]. Caveolin-mediated endocytosis is a type of cholesterol and dynamin-dependent, and receptor-mediated pathway, involving 50-100 $\mathrm{nm}$ invaginations of the plasma membrane [80]. In contrast to the receptor-mediated pathways, macropinocytosis is a form of bulk fluid intake, mediated by cytoskeletal rearrangement to create membrane extensions to trap a large vesicle $(0.2-5 \mu \mathrm{m})$ and fuse it back to the membrane for endocytotic uptake. It is a form of nonspecific bulk fluid uptake in the absence of any specific receptor [81]. Micropinocytosis involves the internalization of nanoparticles of $<0.2 \mu \mathrm{m}$ via both clathrin-coated and uncoated vesicles [82].

The cellular uptake pathway of DNA complexed nanocarriers can be affected by several factors, including size, surface charge, particle shape, surface modifications, cell type and culture Conditions [9,12,77]. As mentioned above, large particles are transported by phagocytosis, whereas smaller particles are taken up by micropinocytosis. In general, nanoparticles formed from non-viral gene delivery vehicles are heterogeneous in size, shape and surface charge, and hence, different types of uptake mechanisms might be active with the same type of delivery vehicle and a single cell type [83]. 
The cell membrane consists of anionic membrane proteins, and hence, positively charged nanoparticles are more easily transported through the cell membrane than that of negatively charged particles. However, the high positive charge will cause cytotoxicity. Therefore, moderately charged particles are ideal for cellular uptake. Zeta potential measurement is used to determine the surface charge of nanoparticles [84].

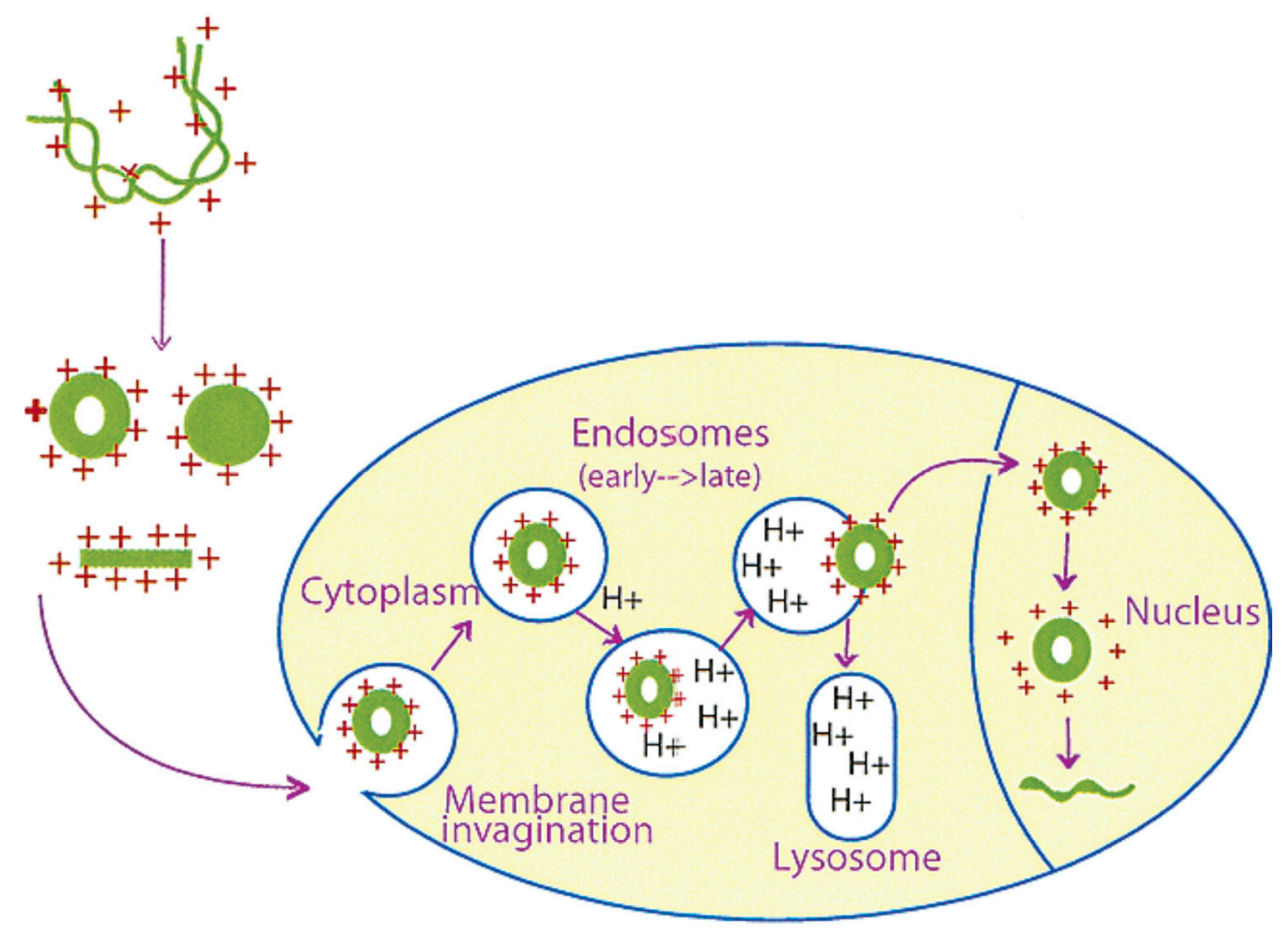

Figure 2. Schematic representation of DNA uptake by mammalian cells. DNA is compacted in the presence of polycations into ordered structures, such as toroids, rods, and spheroids. These particles interact with the anionic proteoglycans at the cell surface and are transported by endocytosis. The cationic agents accumulate in the acidic vesicles, increase the $\mathrm{pH}$ of the endosomes, and inhibit the degradation of DNA by lysosomal enzymes. They also sustain a proton influx, which destabilizes the endosome, and release DNA. The DNA then is translocated to the nucleus either through the nuclear pore or with the aid of nuclear localization signals, and decondenses after separation from the cationic delivery vehicle. Adapted with permission from Reference [9].

The efficacy of membrane transport differs with cell type even if the delivery vehicle and genetic material are the same. Our studies showed significant differences in the level of transfection of $22 \mathrm{kDa}$ linear polyethyleneimine (PEI) treated plasmid DNA with luciferase gene in three breast cancer cell lines; MCF-7, SK-BR3 and T-47D [85]. Cellular targetability can be accomplished by cell surface receptors, such as hyaluronic acid (HA). Nanoparticles containing HA are selectively taken up by MDA-MB-435 cell line, which is rich in CD44 receptors [86]. There have also been many attempts to decorate the surface of nanoparticles with different kinds of targeting motifs to enhance cellular targetability by receptor-mediated endocytosis. For example, the RGD peptide sequence has been incorporated into nanoparticles to make use of the peptide's ability to recognize integrins that are overexpressed on tumor cells or the angiogenic endothelial cells of the tumor vasculature [87]. Conjugation with polyethylene glycol (PEG) increases the serum half-life of nanoparticles, thereby increasing their pharmacokinetics and biodistribution [88]. Therefore, copolymers of PEG and polymeric nanocarriers containing the RGD peptide sequence are effective for cellular targeting and improved serum stability [89]. 


\section{Synthetic Polymers for Gene Delivery}

The cationic molecules which are currently under development as gene delivery vehicles are organic cations, including cationic lipids, polyamine-based polymers, chitosan-based polymers, dendrimers, and polyethyleneimine (PEI) [90-92]. These polymers interact with DNA and provoke the formation of compact nano-sized polyplexes [12]. The charge neutralized compact polyplex core protects enclosed nucleic acids from nucleases, and hence, maintain their stability and integrity until the cellular uptake process occurs $[39,93,94]$. Although PEI is a non-biodegradable polymer, it is included herein because it represents a polymer showing high transfection efficiency and could be made biodegradable by appropriate modifications.

\subsection{Polyethyleneimine and Its Biodegradable Derivatives}

Amongst the various cationic polymers containing amine group in their backbone, polyethyleneimine has been the most extensively studied agent since 1995, when Boussif et al. described it as an effective gene transfection agent [95-98]. PEI has been synthesized in two different forms, branched and linear (Figure 3), and both forms have demonstrated high transfection capability both in vivo and in vitro [85,95-99]. The transfection efficiency of PEI depends on several factors, including, target cell type, molecular weight (MW) and structure of the PEI (branched as opposed to linear) [85]. Approximately $20 \%$ of the nitrogen of PEI is protonated under physiological conditions [100]. Therefore, PEI could envelope negatively charged DNA molecules, and protect them from lysosomal degradation and lead to higher expression of the transfected gene [101]. Using fluorescent-labeled PEI and DNA, Godbey et al. [102] and Venketeswaran et al. [85] found that PEI/DNA complexes attach to cell surfaces and migrate into clumps that are endocytosed. In addition, endocytosed PEI, whether administered with or without DNA, could undergo nuclear localization in the form of ordered structures. However, nuclear delivery of DNA was more facile with a $22 \mathrm{kDa}$ linear PEI compared to that of branched PEI [85].

A<smiles>CCCNCCNCCNCCNCCNC</smiles><smiles>CCCNCCN(CCN)CCN(CCNCCN)CCN(CCNC)CCN(CCN)CCN</smiles>

Figure 3. Chemical structures of linear (A) and branched (B) polyethyleneimine. 
Despite its ability to deliver DNA and oligonucleotides in cellular and animal models, PEI suffers from the critical shortcoming of non-degradability that leads to severe cytotoxic effects $[31,103,104]$. In addition, stability in serum circulation, efficient intracellular release and low toxicity are important criteria for using cationic polymers as gene delivery vehicles. Therefore, several investigators have attempted to synthesize PEI derivatives with degradable linkages [104-107].

Lee et al. synthesized reducible linear PEI containing disulfides that exhibited transfection efficiency comparable to PEI and high cell viability [107]. Bifunctional cross-linkers, such as dimethyl-3,3' dithiopropionimidate (DTBP) and dithio-bis-succinimidyl propionate could react with primary amines, generating high molecular weight reducible polymers. PEI cross-linked with homobifunctional, amine reactive, reducible, and cross-linking reagents was tested for its transfection efficiency in $\mathrm{CHO}$ cells and showed that the modified polymers mediated different levels of transfection-based on cross-linking agent, the extent of cross-linking and N/P (nitrogen to phosphate) ratios [108]. An improvement in the efficiency of low-molecular-weight PEI is provided by the synthesis of dipicolylamine-based disulfide-containing zinc (II)-coordinated module (Zn-DDAC) [109]. Optimal Zn-coordinated polymeric vector induced up to 2-orders of magnitude higher luciferase activity than that of commercial transfection reagents. In a different approach, Albuquerque et al. constructed block co-polymers of PEI with poly(2-(dimethyl amino)ethyl methacrylate) (PDMA) and poly(2-(diethyl amino)ethyl methacrylate) (PDEA) for the optimization of DNA condensation and cellular transport [110].

Heparin-polyethyleneimine (HPEI) nanogels are another group of biodegradable PEI conjugates [111]. After intravenous administration, HPEI degraded, and the degradation products were excreted through urine. HPEI nanogels had excellent transfection efficiency, low cytotoxicity, and better blood compatibility than $25 \mathrm{kDa}$ PEI. In addition, pVSVMP/HPEI complexes inhibited the growth of pulmonary metastases [112]. Low MW PEI was also modified by the stepwise reactions with methylacrylate (aza-Michael reaction) and amidation with tetraethylenepentamine (TEPA) [113]. The resultant biodegradable copolymers were excellent transfection agents for plasmid DNA and siRNA in CHO and A549 cells and had target gene silencing ability without compromising biocompatibility. Targeted delivery of siRNA for gene silencing was accomplished by preparing polyethylenimine-graft-polycaprolactone-block-poly(ethylene glycol)-folate (PEI-PCL-PEG-Fol) (Figure 4) [114].
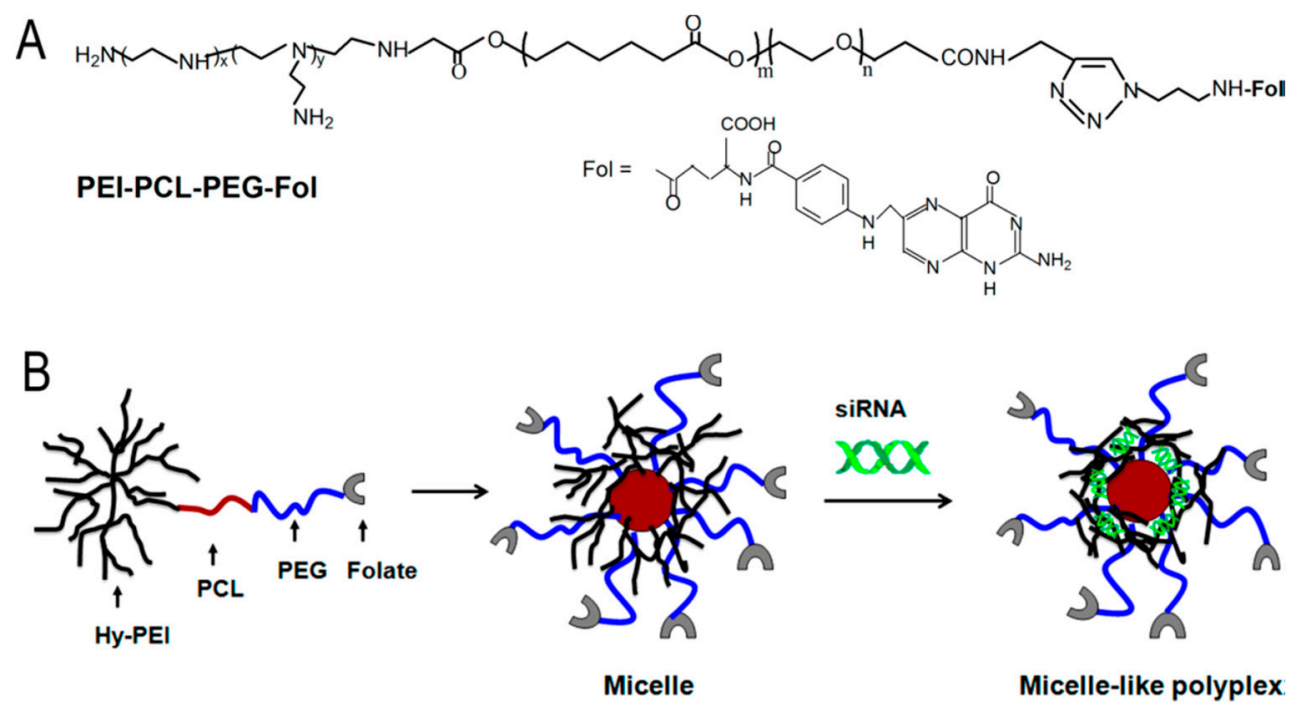

Figure 4. Chemical structure of polyethylenimine-graft-polycaprolactone-block-poly(ethylene glycol)-folate (PEI-PCL-PEG-Fol) (A) and schematic illustration of the micelle-like polyplex formation (B). Adapted with permission from Reference [114]. 
PEI-PCL-PEG-Fol/siRNA micelleplexes showed enhanced cellular uptake and in vitro gene silencing in SKOV-3 ovarian cancer cells that expressed a high level of folic acid receptor, compared to that of non-folate conjugated copolymers [114]. Similar results were found with xenograft models also. Miscelles prepared by grafting branched $25 \mathrm{kDa}$, and PEG on poly[( $\varepsilon$-caprolactone)-co-glycolide] (CG) showed a high level of degradation after cellular internalization [115]. These micelle-based polyplexes showed high DNA transfection activity, as demonstrated by reporter gene-expression and siRNA mediated gene knockdown. PEI-related cytotoxicity was reduced by the incorporation of PEG, with the additional advantage of high serum stability of both DNA and siRNA polyplexes. Tumor targeting was also achieved by cross-liking low MW PEI with N-octyl-N-quaternary chitosan (OTMCS), and then conjugated with a trifunctional peptide (RGDC-TAT-NLS) [116]. The delivery vehicle, thus, prepared (OTMCS-PEI-R18) showed controlled degradation and DNA condensing and nuclear transportation capacity.

Ruan et al. modified low MW (1.2 kDa) PEI through a cross-linking reaction to introduce boric acid ester bond to make it susceptible to biodegradation by reactive oxygen species (ROS) [117]. Further modification of this polymer with substance $\mathrm{P}(\mathrm{SP})$ as the targeting ligand through PEG produced a conjugated polymer that had excellent biocompatibility, ROS cleavability ad transfection efficacy and gene silencing activity in vitro and satisfactory antitumor activity in vivo. A recent study shows that linking of 600 Da PEI with biodegradable bridges of aromatic rings could enhance the DNA binding ability of low MW PEI and increase its stability and transfection efficacy [118].

Grafting of PEI with chitosan, PEG and dextran also provided efficient and biodegradable gene delivery vehicles [119]. Conjugates of low MW PEI with depolymerized chitosans (7 and $10 \mathrm{kDa}$ ) interacted efficiently with DNA to produce nanoparticles of 100-160 nm [120]. These nanoparticles showed efficient transfection ability in vitro. Luciferase reporter gene analysis in male Balb/c mice receiving intravenous administration of the polyplex showed higher gene transfer ability compared to unconjugated chitosan and PEI-based polyplexes. Tseng et al. prepared PEI conjugates with dextran and folate and found that their toxicity was less than that of PEI [121]. The excellent transfection ability of these conjugates could be the release of plasmids from endosomes because the conjugated molecules hindered the protonation of PEI.

Another natural polymer used for modifying PEI is pullulan, a polysaccharide polymer consisting of maltotriose units [122]. PEI conjugated with different MWs of pullulan (5900 and 107,000 Da) was complexed with Apo B-siRNA, and injected into the liver of mice. Introduction of pullulan into PEI dramatically decreased mortality and lung damage in mice after systemic injection as compared to injection of PEI alone. The vector prepared with high MW pullulan was more efficient in serum stability and gene expression compared to that prepared with the low MW pullulan. Wang et al. synthesized pullulan-PEI (P-PEI) conjugates and modified it by conjugating with folic acid. The resulting polymer was biodegradable, and transported pDNA with excellent efficacy in different cell types [123]. The P-PEI-FA/pDNA complex showed higher gene transfection and gene silencing efficiency at N/P ratio of 6.25 compared to the vector lacking pullulan. P-PEI-FA/siRNA can also deliver FAM-labeled siRNA to endosomes and escape. An amphiphilic bifunctional derivative of pullulan was also synthesized by conjugating desoxycholic acid and branched $1000 \mathrm{Da}$ PEI onto pullulan [124]. The resulting polymer conjugate showed excellent blood compatibility, low cytotoxicity and sustained drug release profile and good DNA-binding ability. These micelles could efficiently transport the p53 gene into MCF-7 cells, and the expressed exogenous p53 protein inhibited the growth of these cancer cells.

Certain amino acids, including lysine-histidine peptides and arginine-rich peptides, were also used to modify low MW PEI to transport plasmids and siRNA [125,126]. The conjugates prepared by linking cell penetrating protein (CPP) with PEG showed excellent gene transfection efficiency in two different lung cancer cell lines, with luciferase reporter gene expression in mouse lungs [127]. The conjugates sizes were generally $<300 \mathrm{~nm}$, thus, enabling them to penetrate through the mucus lining of the lung and reach the target cells. Taken together, there are multiple approaches to reduce the toxicity of PEI by conjugation with biodegradable molecules. 


\subsection{Poly- $\beta$-Aminoesters}

Aminoesters are a group of biodegradable polymers that have cationic amino groups and hydrolysable ester linkages [128]. A typical synthesis of a poly- $\beta$-aminoester (PBAE) is illustrated in Figure 5 .

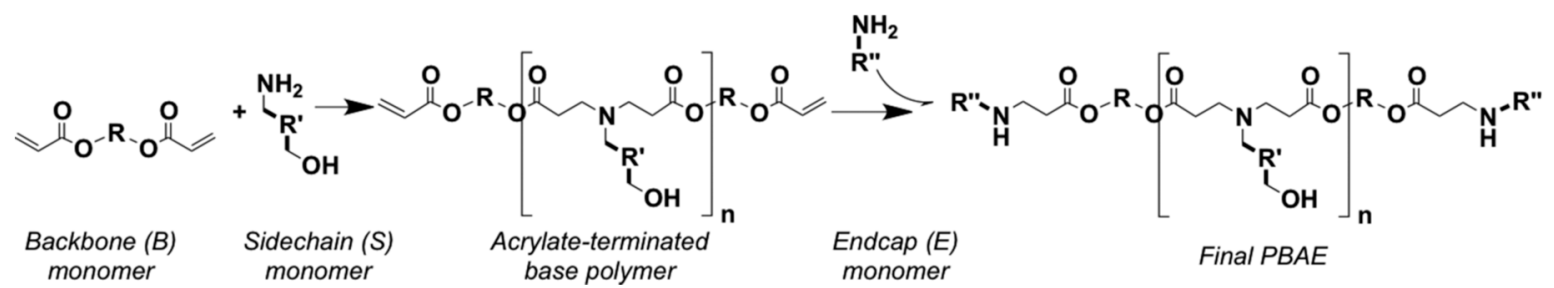

Figure 5. PBAE synthesis reaction scheme. Adapted with permission from Reference [129].

PBAE molecules are capable of interacting with DNA by electrostatic forces to produce nanoparticles of 100-200 nm diameter [130]. They are non-cytotoxic and biodegradable with a half-life of 1-7 $\mathrm{h}$ in aqueous solutions [131,132]. Guerrero-Ca'zares et al. synthesized a panel of PBAE and tested their efficacy in human glioblastoma cells in vitro and in vivo. Nanoparticles formed with PBAE and DNA showed excellent transfection ability in brain tumor initiating cells in vitro even when these cells were grown in 3D oncospheres. In addition, cell specificity was evident in the patient-derived orthotopic murine model of human glioblastoma [131].

Enzyme-catalyzed copolymerizaton of the lactone with dialkyl diester and amino diols produced polyamine(co-esters) that could condense DNA and undergo facile cellular transport in a variety of cells, including human embryonic kidney 293, U87-MG, and 9L cell lines [133]. Targeted delivery of the pro-apoptotic TRAL gene by these agents showed significant inhibition of tumor growth in tumor xenograft models, with minimal toxicity in vitro and in vivo. PBAE could also recognize minicircle DNA to form nanoparticles for delivery in kidney 293 cells and mouse embryonic fibroblasts, as model cell types [134]. Intraperitoneal injection of minicircle DNA in vivo resulted in high transgene expression, and the level of expression was double with PBAE complexed DNA compared to control experiments. Mastorakos et al. further developed highly stable PBAE-based DNA nanoparticles and tested their ability to penetrate the nanoporous and highly adhesive mucous airways as a potential therapeutic approach for respiratory diseases and lung cancer [135]. In addition, these PBAE-based mucus-penetrating DNA nanoparticles (PBAE-MPPs) provided uniform and high-level transgene expression throughout the mouse lungs, superior to several gold-standard gene delivery systems. Transgene expression was robust for more than four months by a single administration in mice. The safety profile of these PBAEs was excellent, following intratracheal administration (Figure 6). In addition, surface-modified poly(lactic-co-glycolic acid) (PLGA)/poly-( $\beta$-aminoester) (PBAE) nanoparticles (NPs) have shown great promise in pulmonary gene delivering and genes editing [136].

PBAE conjugation with $5 \mathrm{kDa}$ PEG was used to increase the circulation half-life of PBAE complexed DNA nanoparticles [136]. The PEG-coated nanoparticles penetrated healthy brain parenchyma and orthotopic brain tumor tissues in rats and achieved widespread transgene expression throughout the tumors in vivo. In addition, these brain penetrating nanoparticles loaded with an anti-cancer plasmid DNA improved the survival time in two aggressive orthotopic brain tumor models in rats [137].

Kauffman et al. synthesized a family of low toxicity poly(amine-co-ester) (PACE) terpolymers via an enzyme-catalyzed polymerization for potential use in transporting plasmid DNA, miRNA, and siRNA [138]. The advantage of PACE polymers is that they could be synthesized in a fine-tuned manner, based on cell type and nucleic acid characteristics. Another approach for cell-type specific delivery is the synthesis of Branched poly(Ester Amine) Quadpolymers (BEAQs) via the Michael addition reactions from small molecule acrylate and amine monomers and then end-capping with amine-containing 
small molecules to assess the influence of polymer branching structure on transfection [139]. BEAQs with moderate degrees of branching were optimal for delivery in serum-containing media. Reducible branched ester-amine quadpolymers (rBEAQs) are also under development to co-encapsulate and deliver DNA plasmids and RNA oligos for applications, such as non-viral CRISPR-mediated gene editing, utilizing Cas9 DNA and siRNA codelivery [140].
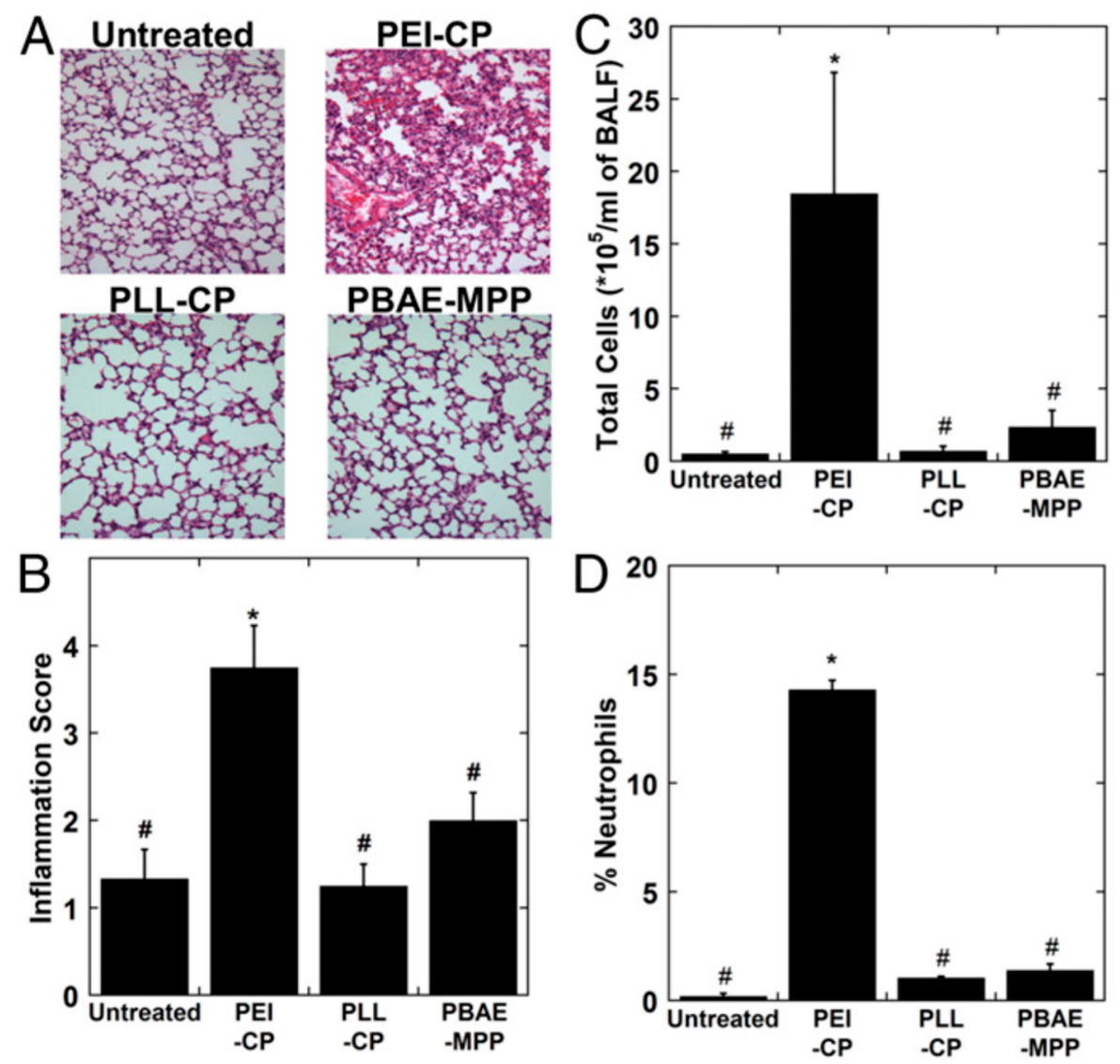

Figure 6. In vivo safety profile of DNA-NPs. (A) Representative images of lung parenchyma $24 \mathrm{~h}$ after administration of DNA-NPs. (B) Histopathological scoring of lung inflammation. (C and D) Total cell counts (C) and \% neutrophils (D) in bronchoalveolar lavage fluid following a single administration of DNA-NPs. Data represent the mean \pm SD $(n=3-5)$. The differences are statistically significant $(p<0.05)$ compared with untreated control $(*)$ or mice dosed with Conventional PEI nanoparticles (PEI-CPs) (\#). Adapted with permission from Reference [135].

\subsection{Poly-L-Lysine (PLL)}

The cationic peptide, PLL (Figure 7) and its low molecular weight analogues, oligolysines were studied for their ability to collapse DNA to nanoparticles and transport DNA to cells [58,141].

Studies by Nayvelt et al. provided mechanistic insights into oligo- and poly-L-lysine-mediated DNA collapse to nanoparticles, with typical morphologies of toroids, spheroids, cubes and rods [58]. Korolev et al. found salt-dependent and salt-independent regimes in the interaction of oligolysines with plasmid DNA [142]. Modification of PEI with PLL enhanced the transfection efficacy of PEI in HeLa cells, in addition to significantly reducing its toxicity [143]. In a recent report, Malik et al. showed that polylysine-modified PEI could provoke genetically engineered mesenchymal stem cells for combinational suicidal gene therapy in glioblastoma [144]. Kodama et al. developed dendrigraft PLL (DGL) as an alternative to PLL and complexed it with $\gamma$-polyglutamic acid ( $\gamma$-PGA) for gene delivery [145]. The ternary complex formed with DNA showed high transfection efficiency in the 
liver, lungs and spleen of experimental animals. Other investigators are synthesizing copolymers of poly-L-lysine for enhanced gene delivery applications [146].

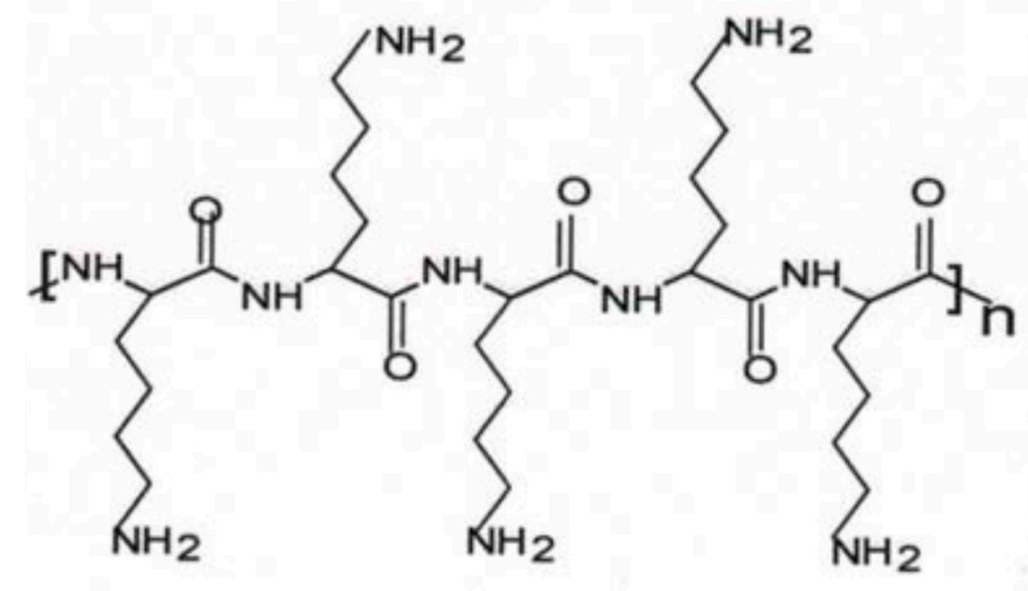

\section{Poly-L-lys ine (linear)}

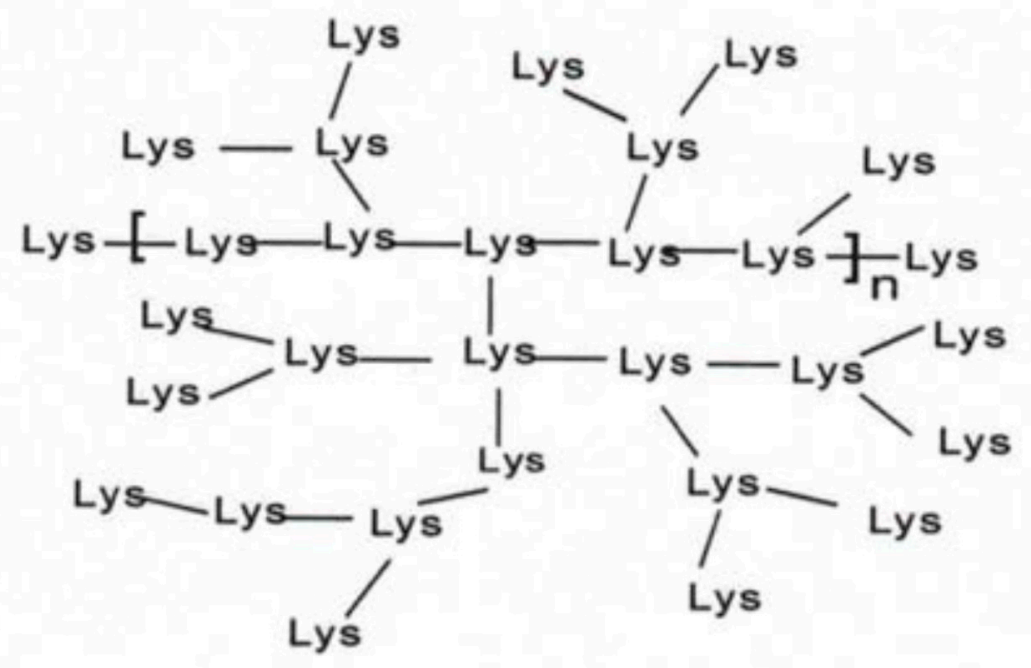

\section{Poly-L-lysine (branched)}

Figure 7. Chemical structures of linear and branched poly-L-lysine.

Several other cationic peptides have also found use as biocompatible and biodegradable gene delivery vehicles. Cell penetrating proteins (CPPs) are a group of cationic peptides that can condense DNA and facilitate DNA/siRNA delivery [147]. CPPs contain $<30$ amino acids and their design is inspired by a trans-activating transcriptional activator (Tat) of human immunodeficiency virus 1 (HIV-1) with the amino acid sequence of GRKKRRQRRRPQ and penetrating peptide of the sequence, RQIKIWFQNRRMKWKK [148]. DNA transporting efficacy of CPPs depends on their sequence length and on the position of the arginine residue in the peptide sequence. Linear and flexible versions of CPPs have been synthesized [147]. Tumor targeting peptides, including RGD and Lyp-1, have also been developed to bind to epithelial cells to transport the DNA cargo directly to tumor cells [149]. 


\section{Natural Carbohydrate Polymers for Gene Delivery}

Several natural polymers (Figure 8) have been studied for gene delivery as these agents are relatively non-toxic and biodegradable [12,150].

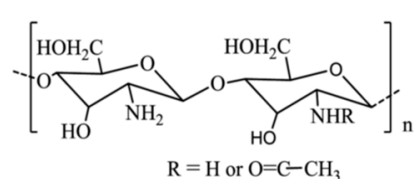

(a) Chitosan

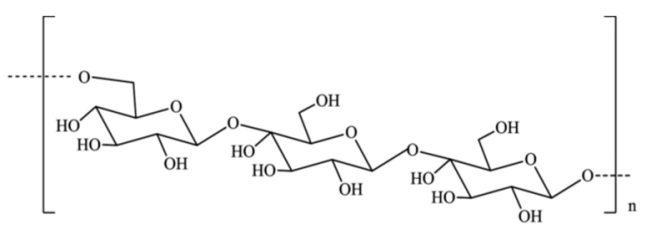

(b) Pullulan

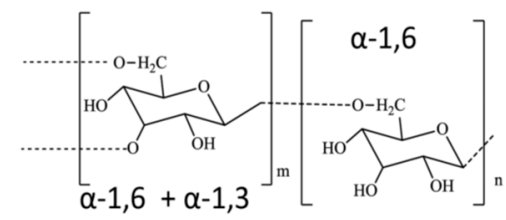

(c) Dextran

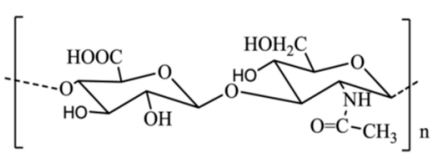

(d) Hyaluronic acid

Figure 8. Chemical structures of commonly used natural polymers for gene delivery. Chitosan (a) is a linear amino polysaccharide comprising randomly distributed $\beta(1,4)$-linked D-glucosamine and N-acetyl-D-glucosamine units. Pullulan $(\mathbf{b})$ is a water-soluble linear polysaccharide, with $\alpha$-1,4-glucopyranose and-1,6-glucopyranose units. Dextran (c) is a carbohydrate polymer composed predominantly of $\alpha-1,6$-linked glucopyranose units with a low degree of 1,3-branching. Hyaluronic acid (HA) (d) is an anionic polysaccharide, a glycosaminoglycan (GAG) composed of repeating polymeric disaccharides of D-glucuronic acid and N-acetyl-D-glucosamine linked by a glucuronidic $\beta(1 \rightarrow 3)$ bond.

\subsection{Chitosan}

Among the natural carbohydrate polymers, chitosan (Figure 8a) has received the most attention as a nanoparticulate drug and gene delivery vehicle [151]. Chitosan condenses DNA to nanoparticles at acidic and neutral $\mathrm{pH}$, due to the presence of amino groups that confer a high positive charge density [152]. It is obtained by the $\mathrm{N}$-deacetylation of chitin, and has randomly distributed $\beta(1,4)$-linked D-glucosamine and N-acetyl-D-glucosamine units. Low immunogenicity, biocompatibility and minimal cytotoxicity are some of the advantages of using chitosan as a gene delivery vehicle. Hydrogels formed by it are compatible with biodegradation by lysozyme and chitosanase enzymes and have low toxicity [153]. As described in the previous section, this property of chitosan has been utilized in preparing conjugates with other polymers, such as PEI, to render them biodegradable. The interaction between chitosan and DNA is electrostatic in origin, as reported for the majority of polycations [154]. Since chitosan is a weak base with a $\mathrm{pK}_{\mathrm{a}}$ of $6.5, \mathrm{pH}$ is an important factor governing facile interaction of its amino groups with DNA. Compaction of DNA with low MW chitosan gives nanoparticles with an average radius of $\sim 150 \mathrm{~nm}$ diameter (Figure 9). Such an interaction appears to be strong enough that the chitosan-DNA complex does not dissociate until it has entered the cell. Once its role is over, chitosan is degraded into the common amino-sugar, $\mathrm{N}$-acetyl glucosamine, which is incorporated into the metabolic pathway of glucoproteins, and is subsequently excreted form the body [155].

The transfection efficiency of chitosan depended on the degree of deacetylation and MW of the chitosan, $\mathrm{pH}$, the presence of serum, chitosan to DNA charge ratio and cell type. The poor solubility in water, low specificity and low transfection efficiency have been major hindrances to its development as an effective gene delivery vector [156]. Morris et al. prepared chitosans of a wide range of MW and degree of deacetylation to determine the optimum conditions of this biopolymer for gene delivery applications [157]. Chitosans of medium MW (49-51 kDa) and a high degree of deacetylation produced stable, uniform-sized nanoparticles. Biological studies with the spherical nano-sized polyplexes formed 
between $50 \mathrm{kDa}$ chitosan of 94\% degree of deacetylation and pEGFP plasmid DNA (N/P ratio = 5) showed excellent gene transfection efficiency at pH 6.5 in HeLa cells. This complex had no cytotoxicity, indicating its potential use as a gene delivery vehicle. This study also showed that chitosan in the MW range of 49-51 kDa could be useful in condensing DNA to deliver nanoparticles of near-uniform size ( 50 nm) for gene delivery applications [157].

a)

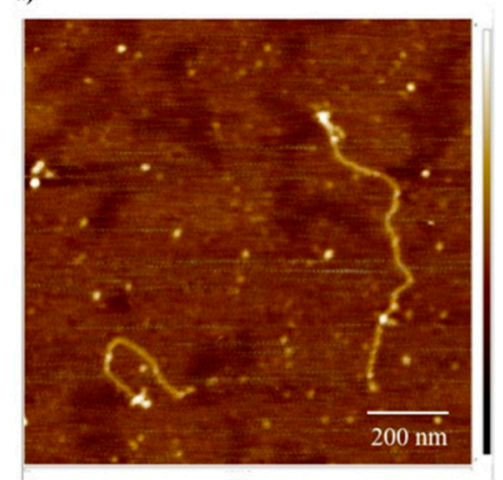

b)

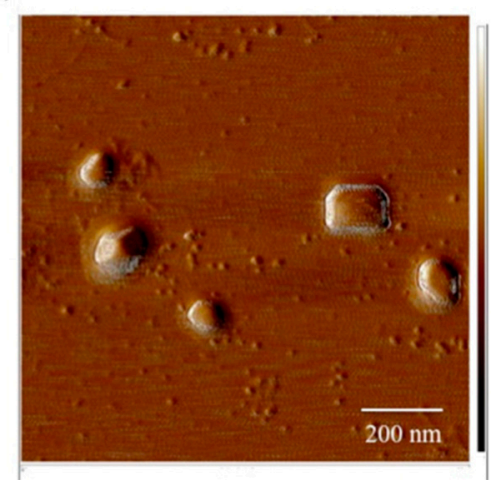

Figure 9. AFM images of DNA and DNA/chitosan complexes. (a) Single chains of DNA prepared in water at a concentration of $7.5 \times 10^{-3} \mathrm{~g} / \mathrm{L}$ and $(\mathbf{b})$ chitosan-DNA complexes formed at a charge ratio of 0.41 with $50 \mathrm{kDa}$ chitosan in $0.01 \mathrm{M} \mathrm{NaCl}$. Scale bar is $200 \mathrm{~nm}$. Adapted with permission from Reference [154].

The presence of hydroxyl and amino groups in the backbone of chitosan makes it amenable to the chemical modification to improve its chemical properties and effectiveness. Quaternization of the amino groups could be used to render medium and low MW chitosans water-soluble over a wide range of $\mathrm{pH}$ and to confer controlled cationic character [157]. Cellular targetability could be introduced by conjugation of folic acid through the quarternized derivative because of the presence of folate receptors on tumor cell $[157,158]$. The conjugated polymer could provoke plasmid DNA condensation to uniformly-sized nanoparticles of $\sim 140 \mathrm{~nm}$ size and high positive surface charge density. The $\mathrm{pH}$ profiles of folic acid conjugated trimethylated depolymerized chitosan suggested that the polymers had endosomal disruption capacity, and the gel electrophoretic mobility band retardation showed efficient condensation of DNA. Folic acid derivatized chitosan, and its DNA complex were less toxic and hemocompatible than that of PEI and its DNA complex. The chitosan complex also showed excellent transfection efficiency, as tested in human KB epidermoid cell line. Plasmid pGL3 was transported to the cell nucleus [159]. The water-solubility and transfection efficiency of chitosans could be improved when the depolymerized trimethylated chitosans were modified with the histidine moiety [159]. Spherical nanoparticles could be formed, and these derivatives could buffer in the $\mathrm{pH}$ range of 10 to 4 . The transfection efficiency of this chitosan conjugate was comparable to that of control PEI. Taken together, the enhanced cellular and nuclear uptake of chitosan conjugates show that chitosan can be modified to yield highly efficient gene delivery vehicles.

Another group of investigators synthesized thiolated methylated N-(4-N,N-dimethyl-aminobenzyl $\mathrm{N}, \mathrm{O}$-carboxymethyl chitosan derivatives to improve the solubility and delivery properties of chitosan [160]. These derivatives had a higher solubility in water compared to that of chitosan and had no significant toxicity against Hek293 kidney cell line in comparison to that of chitosan. Rahmani et al. prepared trimethyl chitosan, methylated 4-N,Ndimethyl aminobenzyl N,O-carboxymethyl chitosan and thiolated trimethyl aminobenzyl chitosan and showed that these polymers could condense DNA to nanoparticles [161]. These nanoparticles exhibited facile transfection in SKOV-2 ovarian and MCF-7 breast cancer cell lines. With siRNA, O-methyl-free N,N,N-trimethylated chitosan showed excellent gene silencing activity comparable to that of PEI in H1299 human lung cancer cells expressing firefly luciferase, indicating the use of chitosan derivatives in siRNA delivery [162]. A recent report 
showed that folic acid-modified polyethylene glycol-chitosan oligosaccharide lactate nanoparticles facilitated siRNA delivery targeted to multiple genes in a pancreatic cancer xenograft model and strongly inhibited retroperitoneal invasion and inhibited peritoneal dissemination compared to the other nanoparticles [163]. Several other modified forms of chitosan are under active investigation for gene delivery applications of different cell types [164-167].

\subsection{Pullulan}

Pullulan (Figure $8 b$ ) is a water-soluble linear polysaccharide, with $\alpha-1,4$-glucopyranose and $\alpha-1,6$-glucopyranose units $[168,169]$. It is non-toxic, non-immunogenic, non-carcinogenic and non-mutagenic and has found applications in food packaging and pharmaceutical industries.

Derivatization of pullulan with cationic molecules, such as spermine, can produce positively charged nanoparticles with an excellent binding affinity toward DNA and gene transfection efficacy [170]. Priya et al. synthesized cationic pullulan by conjugating it with protamine [171]. This polymer could protect DNA from degradation and had excellent haemocompatibility and improved cellular viability. A recent study showed the synthesis of a redox-responsive system by combining a charge- reversible pullulan derivative (CAPL) and disulfide-containing PBAE for the co-delivery of a gene and a chemotherapeutic agent [172]. This agent could condense DNA and deliver a dye-labeled pDNA in human hepatoma HepG2 cells. Pullulan conjugation also enhanced the gene delivery efficacy of PAMAM dendrimer in HepG2 cell line [173].

\subsection{Dextran}

Dextran (Figure 8c) is another carbohydrate polymer with applications in biomedicine and gene delivery. It is composed predominantly of $\alpha-1,6$-linked glucopyranose units with a low degree of 1,3-branching [12,174]. Cationic, biodegradable dextran hydrogel nanoparticles could be prepared by derivatization with cationic methacrylate monomers for siRNA delivery [175]. In addition, negatively charged dextran sulfate could form polyelectrolyte complexes with positively charged polymers, such as poly-L-arginine for siRNA delivery [176]. Dextran-grafted branched PEI was found to be effective to improve the stability of the PEI complexes with DNA in the presence of BSA [177]. Dextran-PEI conjugates were less toxic than unmodified PEI, as determined by the MTT assay [178]. Nanoparticles formed by the complexation of polyallyamine (PAA)-dextran conjugate with DNA were more efficiently transfected than that of PAA-DNA nanoparticles [179]. Chitosan-dextran conjugates showed excellent transfection efficiency of frizzled-related protein 4 (SFRP4) in both JU77 and ONE58 cell lines [180]. Histidine $(\mathrm{H})$-containing peptide-grafted dextran (D-RxHy) displayed a 6-8-fold higher luciferase expression compared to that of $25 \mathrm{kDa}$ branched PEI [181].

\subsection{Hyaluronic Acid (HA)}

HA (Figure 8d) is an anionic polysaccharide that has found biomedical applications, including drug and gene delivery. It is composed of D-glucuronic acid and N-acetyl-D-glucosamine [182]. It binds with the CD44 receptor, that is overexpressed on the surface of many types of tumor cells, and hence, it is an excellent vehicle for targeted delivery of genes and drugs to cancer cells. HA can form nanogels by electrostatic interaction with polycations, such as polyarginine [183]. The interaction of siRNA and HA by van der Waals forces has been exploited for gene silencing in a CD44-positive human osteocarcinoma cell line (MG63) and in human mesenchymal stromal cells [184]. Nanoparticle formulations prepared by the complexation of HA conjugated PEG (HA-PEG) and HA-PEI produced excellent results in gene transfection and gene expression with negligible cytotoxicity in HeLa and A549 human lung cancer cell lines [185]. HA was complexed with PEI and the complex used to deliver MMP13 gene in a mouse model of liver fibrosis, with excellent results [186]. Lipoplexes containing plasmid DNA within polyelectrolyte multilayers composed of glycol-chitosan (Glyc-CHI) and hyaluronic acid (HA) was used to transfect NIH2T3 fibroblasts and HEK293 kidney cells in vitro [187]. Ternary nanocomplexes of HA conjugates with poly(hexamethylene biguanide) and chitosan were to deliver an anti-KRAS 
siRNA to colorectal cancer cells, exploiting the interaction of HA with CD44 as a means to achieve selective targeting of CD44-positive cancer cells [188]. Multilayers of HA/PEI were also constructed to deliver siRNA and gene silencing [189].

We have summarized work on four natural biodegradable polymers above; however, there are several other molecules, such as heparin, chondroitin sulfate, and alginate that are under investigation as gene delivery vehicles [12].

Table 1 shows a summary of the modifications on polymers to confer biodegradability and enhance cellular transportation.

Table 1. Polymer modifications to facilitate biodegradability and/or cellular transport.

\begin{tabular}{|c|c|c|}
\hline Polymer & Modification & References \\
\hline Polyethleneimine (PEI) & $\begin{array}{l}\text { Disulfide linkage } \\
\text { PDMA/PDEA copolymer } \\
\text { Heparin } \\
\text { TEPA } \\
\text { PCL-PEG-FA } \\
\text { PCL-CG } \\
\text { Chitosan } \\
\text { Boric acid } \\
\text { Aromatic ring bridges } \\
\text { Dextran } \\
\text { Pullulan/FA } \\
\text { Desoxychlic acid } \\
\text { Amino acids }\end{array}$ & $\begin{array}{l}{[107-109]} \\
{[110]} \\
{[111,112]} \\
{[113]} \\
{[114]} \\
{[115]} \\
{[116,119,120]} \\
{[117]} \\
{[118]} \\
{[121]} \\
{[122]} \\
{[123,124]} \\
{[125-127]}\end{array}$ \\
\hline PBAE & $\begin{array}{l}\text { PLGA/PEG } \\
\text { PACE } \\
\text { BEAQ }\end{array}$ & $\begin{array}{l}{[136]} \\
{[138]} \\
{[139]}\end{array}$ \\
\hline PLL & $\begin{array}{l}\text { PEI } \\
\gamma \text {-PGA }\end{array}$ & $\begin{array}{l}{[143,144]} \\
{[145]} \\
\end{array}$ \\
\hline Chitosan & $\begin{array}{l}\text { FA } \\
\text { Dimethylaminobenzyl } \\
\text { FA/PEG }\end{array}$ & $\begin{array}{l}{[157,158]} \\
{[160,161]} \\
{[163]}\end{array}$ \\
\hline Pullulan & $\begin{array}{l}\text { Spermine } \\
\text { Protamine } \\
\text { PBAE } \\
\text { PMAM }\end{array}$ & $\begin{array}{l}{[170]} \\
{[171]} \\
{[172]} \\
{[173]}\end{array}$ \\
\hline Dextran & $\begin{array}{l}\text { PEI/Polyarginine } \\
\text { PAA } \\
\text { Chitosan } \\
\text { Histidine }\end{array}$ & $\begin{array}{l}{[176]} \\
{[179]} \\
{[180]} \\
{[181]}\end{array}$ \\
\hline Hyaluronic Acid, HA & $\begin{array}{l}\text { PA/PEI } \\
\text { PEG } \\
\text { Glycol } \\
\text { Biguanidine }\end{array}$ & $\begin{array}{l}{[183,186]} \\
{[185]} \\
{[187]} \\
{[188]}\end{array}$ \\
\hline
\end{tabular}

\section{Concluding Remarks}

Polymer-based non-viral gene carriers have been developed, due to their merits in safety, including the avoidance of potential immunogenicity and toxicity, the possibility of repeated administration, and the ease of establishing good manufacturing practice (GMP) [50]. Although preclinical studies and human clinical trials demonstrated therapeutic benefit of several gene therapy approaches, efficient gene delivery remains a key obstacle for moving several drug candidates to the clinic.

There are several systemic and cellular barriers, including serum proteins in the bloodstream, cell membrane, endosomal compartment and nuclear membrane. Polymer design and modifications have 
been successfully used to circumvent these barriers. Structural modifications include incorporations of guanidinium group, carboxyl group, disulfide bond, alkyl chain, branching, acetyl groups, benzoyl groups, and quaternary nicotinamide moieties to facilitate DNA condensation, cellular uptake, endosomal escape, nuclear entry and gene expression (Table 1). Polymer complexed DNA nanoparticles can be administered by injection, infusion and/or inhalation for realizing the potential therapeutic benefits.

\section{Future Directions}

The cellular transport of DNA is a complicated process, and the mechanistic aspects of this process are not clearly understood at present. The development of polymeric gene delivery vehicles focused on molecules that could compact DNA to nanoparticles and transport the genetic material in a facile manner, produce no immunogenic response and degrade to small molecules that could easily get eliminated from the body. Although significant progress has been made in the development of DNA condensation agents, the discovery of an ideal biodegradable delivery vehicle has not been accomplished. Modification of currently existing natural and synthetic polymers with linker groups that can undergo hydrolysis and enzymatic degradation is making significant progress.

Author Contributions: Conceptualization, T.J.T., and C.K.S.P.; Literature search, organization, and critical analysis, T.J.T., H.-A.T.-R., and C.K.S.P.; Review and editing of the manuscript, T.J.T., H.-A.T.-R., and C.K.S.P.

Funding: The financial support from the Natural Sciences and Engineering Research Council of Canada (NSERC) for this review is highly appreciated.

Conflicts of Interest: The authors declare no conflict of interest.

\section{References}

1. Doshi, B.; Arruda, S.V.R. Gene therapy for hemophilia: What does the future hold? Ther. Adv. Hematol. 2018, 9, 273-293. [CrossRef] [PubMed]

2. Donde, A.; Wong, P.C.; Chen, L.L. Challenges and advances in gene therapy approaches for neurodegenerative disorders. Curr. Gene Ther. 2017, 17, 187-193. [CrossRef] [PubMed]

3. Dias, M.F.; Joo, K.; Kemp, J.A.; Fialho, S.L.; da Silva Cunha, A., Jr.; Woo, S.J.; Kwon, Y.J. Molecular genetics and emerging therapies for retinitis pigmentosa: Basic research and clinical perspectives. Prog. Retin. Eye Res. 2018, 2018. 63, 107-131. [CrossRef]

4. Russell, S.; Bennett, J.; Wellman, J.A.; Chung, D.C.; Yu, Z.F.; Tillman, A.; Cross, D.; Wittes, J.; Pappas, J.; Elci, O.; et al. Efficacy and safety of voretigene neparvovec (AAV2-hRPE65v2) in patients with RPE65-mediated inherited retinal dystrophy: A randomised, controlled, open-label, phase 3 trial. Lancet 2017, 390, 849-860. [CrossRef]

5. Sporikova, Z.; Koudelakova, V.; Trojanec, R.; Hajduch, M. Genetic markers in triple-negative breast cancer. Clin. Breast Cancer 2018, 18, e841-e850. [CrossRef] [PubMed]

6. Lai, W.F.; Wong, W.T. Design of polymeric gene carriers for effective intracellular delivery. Trends Biotechnol. 2018, 36, 713-728. [CrossRef] [PubMed]

7. Jiang, X.; Fitch, S.; Wang, C.; Wilson, C.; Li, J.; Grant, G.A.; Yang, F. Nanoparticle engineered TRAIL-overexpressing adipose-derived stem cells target and eradicate glioblastoma via intracranial delivery. Proc. Natl. Acad. Sci. USA 2016, 113, 13857-13862. [CrossRef]

8. Agostinelli, E.; Vianello, F.; Magliulo, G.; Thomas, T.; Thomas, T.J. Nanoparticle strategies for cancer therapeutics: Nucleic acids, polyamines, bovine serum amine oxidase and iron oxide nanoparticles. Int. J. Oncol. 2015, 46, 5-16. [CrossRef]

9. Vijayanathan, V.; Thomas, T.; Thomas, T.J. DNA nanoparticles and development of DNA delivery vehicles for gene therapy. Biochemistry 2002, 41, 14085-14094. [CrossRef]

10. Youngblood, R.L.; Truong, N.F; Segura, T.; Shea, L.D. It's All in the delivery: Designing hydrogels for cell and non-viral gene therapies. Mol. Ther. 2018, 26, 2087-2106. [CrossRef]

11. Nelson, C.E.; Gersbach, C.A. Engineering delivery vehicles for genome editing. Annu. Rev. Chem. Biomol. Eng. 2016, 7, 637-662. [CrossRef] [PubMed] 
12. Li, Y.; Maciel, D.; Rodrigues, J.; Shi, X.; Tomás, H. Biodegradable polymer nanogels for drug/nucleic acid delivery. Chem. Rev. 2015, 115, 8564-8608. [CrossRef] [PubMed]

13. Guo, X.; Huang, L. Recent advances in nonviral vectors for gene delivery. Acc. Chem. Res. 2012, 45, 971-979. [CrossRef] [PubMed]

14. Rey-Rico, A.; Cucchiarini, M. Smart and controllable rAAV gene delivery carriers in progenitor cells for human musculoskeletal regenerative medicine with a focus on the articular cartilage. Curr. Gene Ther. 2017, 17, 127-138. [CrossRef]

15. Wasala, N.B.; Shin, J.H.; Duan, D. The evolution of heart gene delivery vectors. J. Gene Med. 2011, 13, 557-565. [CrossRef]

16. Pannier, A.K.; Shea, L.D. Controlled release systems for DNA delivery. Mol. Ther. 2004, 10, 19-26. [CrossRef]

17. Zheng, H.; Tang, C.; Yin, C. Exploring advantages/disadvantages and improvements in overcoming gene delivery barriers of amino acid modified trimethylated chitosan. Pharm. Res. 2015, 32, 2038-2050. [CrossRef]

18. Jung, S.J.; Kasala, D.; Choi, J.W.; Lee, S.H.; Hwang, J.K.; Kim, S.W.; Yun, C.O. Safety profiles and antitumor efficacy of oncolytic adenovirus coated with bioreducible polymer in the treatment of a CAR negative tumor model. Biomacromolecules 2015, 16, 87-96. [CrossRef]

19. Kwiatkowska, A.; Nandhu, M.S.; Behera, P.; Chiocca, E.A.; Viapiano, M.S. Strategies in gene therapy for glioblastoma. Cancers 2013, 5, 1271-1305. [CrossRef]

20. Chira, S.; Jackson, C.S.; Oprea, I.; Ozturk, F.; Pepper, M.S.; Diaconu, I.; Braicu, C.; Raduly, L.Z.; Calin, G.A.; Berindan-Neagoe, I. Progresses towards safe and efficient gene therapy vectors. Oncotarget 2015, 6, 30675-30703. [CrossRef]

21. Mancheño-Corvo, P.; Martín-Duque, P. Viral gene therapy. Clin. Transl. Oncol. 2006, 8, 858-867. [CrossRef] [PubMed]

22. Milone, M.C.; O’Doherty, U. Clinical use of lentiviral vectors. Leukemia 2018, 32, 1529-1541. [CrossRef] [PubMed]

23. Brun, M.J.; Gomez, E.J.; Suh, J. Stimulus-responsive viral vectors for controlled delivery of therapeutics. J. Control. Release 2017, 267, 80-89. [CrossRef]

24. Naso, M.; Tomkowicz, F.B.; Perry, W.L.; Strohl, W.R. Adeno-associated virus (AAV) as a vector for gene therapy. BioDrugs 2017, 31, 317-334. [CrossRef] [PubMed]

25. Zhou, Z.; Liu, X.; Zhu, D.; Wang, Y.; Zhang, Z.; Zhou, X.; Qiu, N.; Chen, X.; Shen, Y. Nonviral cancer gene therapy: Delivery cascade and vector nanoproperty integration. Adv. Drug. Deliv. Rev. 2017, 115, 115-154. [CrossRef] [PubMed]

26. Thomas, T.J.; Thomas, T. Collapse of DNA in packaging and cellular transport. Int. J. Biol. Macromol. 2018, 109, 36-48. [CrossRef]

27. Thomas, T.J.; Tajmir-Riahi, H.A.; Thomas, T. Polyamine-DNA interactions and development of gene delivery vehicles. Amino Acids 2016, 48, 2423-2431. [CrossRef]

28. Cardoso, A.L.; Simões, S.; de Almeida, L.P.; Pelisek, J.; Culmsee, C.; Wagner, E.; Pedroso de Lima, M.C. siRNA delivery by a transferrin-associated lipid-based vector: A non-viral strategy to mediate gene silencing. J. Gene Med. 2007, 9, 170-183. [CrossRef]

29. Zhang, Y.; Ren, T.; Gou, J.; Zhang, L.; Tao, X.; Tian, B.; Tian, P.; Yu, D.; Song, J.; Liu, X.; et al. Strategies for improving the payload of small molecular drugs in polymeric micelles. J. Control. Release 2017, 261, 352-366. [CrossRef]

30. Viola, B.M.; Abraham, T.E.; Arathi, D.S.; Sreekumar, E.; Pillai, M.R.; Thomas, T.J.; Pillai, C.K.S. Synthesis and characterization of novel water-soluble polyamide based on spermine and aspartic acid as a potential gene delivery vehicle. eXPRESS Polym. Lett. 2008, 2, 330-338. [CrossRef]

31. Pandey, A.P.; Sawant, K.K. Polyethylenimine: A versatile, multifunctional non-viral vector for nucleic acid delivery. Mater. Sci. Eng. C Mater. Biol. Appl. 2016, 68, 904-918. [CrossRef] [PubMed]

32. Ramamoorth, M.; Narvekar, A. Non-Viral Vectors in Gene Therapy- An Overview. J Clin Diagn Res. 2015, 9 , GE01-GE06. [CrossRef] [PubMed]

33. Zhi, D.; Bai, Y.; Yang, J.; Cui, S.; Zhao, Y.; Chen, H.; Zhang, S. A review on cationic lipids with different linkers for gene delivery. Adv. Colloid Interface Sci. 2018, 253, 117-140. [CrossRef] [PubMed]

34. Samal, S.K.; Dash, M.; Van Vlierberghe, S.; Kaplan, D.L.; Chiellini, E.; Blitterswijk, C.; Moroni, L.; Dubruel, P. Cationic polymers and their therapeutic potential. Chem. Soc. Rev. 2012, 41,7147-7194. [CrossRef] [PubMed] 
35. Araújo, R.V.; Santos, S.D.S.; Igne Ferreira, E.; Giarolla, J. New advances in general biomedical applications of PAMAM dendrimers. Molecules 2018, 23, 2849. [CrossRef]

36. Altwaijry, N.; Somani, S.; Dufès, C. Targeted nonviral gene therapy in prostate cancer. Int. J. Nanomed. 2018, 13, 5753-5767. [CrossRef]

37. Hong, S.J.; Ahn, M.H.; Sangshetti, J.; Choung, P.H.; Arote, R.B. Sugar-based gene delivery systems: Current knowledge and new perspectives. Carbohydr. Polym. 2018, 181, 1180-1193. [CrossRef]

38. Vijayanathan, V.; Agostinelli, E.; Thomas, T.; Thomas, T.J. Innovative approaches to the use of polyamines for DNA nanoparticle preparation for gene therapy. Amino Acids 2014, 46, 499-509. [CrossRef]

39. Nayvelt, I.; Hyvönen, M.T.; Alhonen, L.; Pandya, I.; Thomas, T.; Khomutov, A.R.; Vepsäläinen, J.; Patel, R.; Keinänen, T.A.; Thomas, T.J. DNA condensation by chiral alpha-methylated polyamine analogues and protection of cellular DNA from oxidative damage. Biomacromolecules 2010, 11, 97-105. [CrossRef]

40. Vijayanathan, V.; Lyall, J.; Thomas, T.; Shirahata, A.; Thomas, T.J. Ionic, structural, and temperature effects on DNA nanoparticles formed by natural and synthetic polyamines. Biomacromolecules 2005, 6, 1097-1103. [CrossRef]

41. Vijayanathan, V.T.; Thomas, T.; Antony, A.; Shirahata, J. Formation of DNA nanoparticles in the presence of novel polyamine analogues: A laser light scattering and atomic force microscopic study. Nucleic Acids Res. 2004, 32, 127-134. [CrossRef] [PubMed]

42. Vijayanathan, V.; Thomas, T.; Shirahata, A.; Thomas, T.J. DNA condensation by polyamines: A laser light scattering study of structural effects. Biochemistry 2001, 40, 13644-13651. [CrossRef] [PubMed]

43. Zinchenko, A. DNA conformational behavior and compaction in biomimetic systems: Toward better understanding of DNA packaging in cell. Adv. Colloid Interface Sci. 2016, 232, 70-79. [CrossRef] [PubMed]

44. Hyodo, M.; Sakurai, Y.; Akita, H.; Harashima, H. "Programmed packaging” for gene delivery. J. Control. Release 2014, 193, 316-323. [CrossRef]

45. Teixeira, H.F.; Bruxel, F.; Fraga, M.; Schuh, R.S.; Zorzi, G.K.; Matte, U.; Fattal, E. Cationic nanoemulsions as nucleic acids delivery systems. Int. J. Pharm. 2017, 534, 356-367. [CrossRef]

46. Liu, S.; Guo, T. Polycation-based ternary gene delivery system. Curr. Drug Metab. 2015, 16, $152-165$. [CrossRef]

47. Pack, D.W.; Hoffman, A.S.; Pun, S.; Stayton, P.S. Design and development of polymers for gene delivery. Nat. Rev. Drug Discov. 2005, 4, 581-593. [CrossRef]

48. Panyam, J.; Labhasetwar, V. Biodegradable nanoparticles for drug and gene delivery to cells and tissue. Adv. Drug Deliv. Rev. 2003, 55, 329-347. [CrossRef]

49. Luten, J.; van Nostrum, C.F.; De Smedt, S.C.; Hennink, W.E. Biodegradable polymers as non-viral carriers for plasmid DNA delivery. J. Control Release 2008, 126, 97-110. [CrossRef]

50. Park, T.G.; Jeong, J.H.; Kim, S.W. Current status of polymeric gene delivery systems. Adv. Drug. Deliv. Rev. 2006, 58, 467-486. [CrossRef]

51. Mastrobattista, E.; Hennink, W.E. Polymers for gene delivery: Charges for success. Nat. Mater. 2012, 11, 10-12. [CrossRef] [PubMed]

52. Al-Dosari, M.S.; Gao, X. Nonviral gene delivery: Principle, limitations, and recent progress. AAPS J. 2009, 11, 671-681. [CrossRef] [PubMed]

53. Priegue, J.M.; Lostalé-Seijo, I.; Crisan, D.; Granja, J.R.; Fernández-Trillo, F.; Montenegro, J. Different-length hydrazone activated polymers for plasmid DNA condensation and cellular transfection. Biomacromolecules 2018, 19, 2638-2649. [CrossRef] [PubMed]

54. Majzoub, R.N.; Ewert, K.K.; Safinya, C.R. Cationic liposome-nucleic acid nanoparticle assemblies with applications in gene delivery and gene silencing. Philos. Trans. A Math. Phys. Eng. Sci. 2016, 374, 20150129. [CrossRef]

55. Kozielski, K.L.; Rui, Y.; Green, J.J. Non-viral nucleic acid containing nanoparticles as cancer therapeutics. Expert Opin. Drug Deliv. 2016, 13, 1475-1487. [CrossRef]

56. Durymanov, M.; Reineke, J. Non-viral delivery of nucleic acids: Insight into mechanisms of overcoming intracellular barriers. Front. Pharmacol. 2018, 9, 971. [CrossRef]

57. Cheng, Y.; Yumul, R.C.; Pun, S.H. Virus-inspired polymer for efficient in vitro and in vivo gene delivery. Angew. Chem. Int. Ed. Engl. 2016, 55, 12013-12017. [CrossRef]

58. Nayvelt, I.; Thomas, T.; Thomas, T.J. Mechanistic differences in DNA nanoparticle formation in the presence of oligolysines and poly-L-lysine. Biomacromolecules 2007, 8, 477-484. [CrossRef] 
59. Thomas, T.; Thomas, T.J. Polyamines in cell growth and cell death: Molecular mechanisms and therapeutic applications. Cell. Mol. Life Sci. 2001, 58, 244-258. [CrossRef]

60. Thomas, T.J.; Bloomfield, V.A. Collapse of DNA caused by trivalent cations: $\mathrm{pH}$ and ionic specificity effects. Biopolymers 1983, 22, 1097-1106. [CrossRef]

61. Guo, Z.; Wang, Y.; Yang, A.; Yang, G. The effect of $\mathrm{pH}$ on charge inversion and condensation of DNA. Soft Matter. 2016, 12, 6669-6674. [CrossRef] [PubMed]

62. Yoo, J.; Aksimentiev, A. The structure and intermolecular forces of DNA condensates. Nucleic Acids Res. 2016, 44, 2036-2046. [CrossRef] [PubMed]

63. N'soukpoé-Kossi, C.N.; Ouameur, A.A.; Thomas, T.; Shirahata, A.; Thomas, T.J.; Tajmir-Riahi, H.A. DNA interaction with antitumor polyamine analogues: A comparison with biogenic polyamines. Biomacromolecules 2008, 9, 2712-2718. [CrossRef] [PubMed]

64. Todd, B.A.; Parsegian, V.A.; Shirahata, A.; Thomas, T.J.; Rau, D.C. Attractive forces between cation condensed DNA double helices. Biophys, J. 2008, 94, 4775-4782. [CrossRef] [PubMed]

65. Leforestier, A.; Siber, A.; Livolant, F.; Podgornik, R. Protein-DNA interactions determine the shapes of DNA toroids condensed in virus capsids. Biophys. J. 2011, 100, 2209-2216. [CrossRef] [PubMed]

66. Saminathan, M.; Thomas, T.; Shirahata, A.; Pillai, C.K.S.; Thomas, T.J. Polyamine structural effects on the induction and stabilization of liquid crystalline DNA: Potential applications to DNA packaging, gene therapy and polyamine therapeutics. Nucleic Acids Res. 2002, 30, 3722-3731. [CrossRef]

67. Saminathan, M.; Antony, T.; Shirahata, A.; Sigal, L.H.; Thomas, T.; Thomas, T.J. Ionic and structural specificity effects of natural and synthetic polyamines on the aggregation and resolubilization of single-, double-, and triple-stranded DNA. Biochemistry 1999, 38, 3821-3830. [CrossRef]

68. Li, C.; Ma, C.; Xu, P.; Gao, Y.; Zhang, J.; Qiao, R.; Zhao, Y. Effective and reversible DNA condensation induced by a simple cyclic/rigid polyamine containing carbonyl moiety. J. Phys. Chem. B 2013, 117, 7857-7867. [CrossRef]

69. Thomas, R.M.; Thomas, T.; Wada, M.; Sigal, L.H.; Shirahata, A.; Thomas, T.J. Facilitation of the cellular uptake of a triplex-forming oligonucleotide by novel polyamine analogues: Structure-activity relationships. Biochemistry 1999, 38, 13328-13337. [CrossRef]

70. Murray-Stewart, T.; Ferrari, E.; Xie, Y.; Yu, F.; Marton, L.J.; Oupicky, D.; Casero, R.A. Biochemical evaluation of the anticancer potential of the polyamine-based nanocarrier Nano11047. PLoS ONE 2017, 12, e0175917.

71. DeRouchey, J.E.; Rau, D.C. Role of amino acid insertions on intermolecular forces between arginine peptide condensed DNA helices: Implications for protamine-DNA packaging in sperm. J. Biol. Chem. 2011, 286, 41985-41992. [CrossRef] [PubMed]

72. Morris, V.B.; Labhasetwar, V. Arginine-rich polyplexes for gene delivery to neuronal cells. Biomaterials 2015, 60, 151-160. [CrossRef] [PubMed]

73. Olden, B.R.; Cheng, E.; Cheng, Y.; Pun, S.H. Identifying key barriers in cationic polymer gene delivery to human T cells. Biomater. Sci. 2019, 7, 789. [CrossRef] [PubMed]

74. Xiang, S.; Tong, H.; Shi, Q.; Fernandes, J.C.; Jin, T.; Da, K.; Zhang, X. Uptake mechanisms of non-viral gene delivery. J. Control Release 2012, 158, 371-378. [CrossRef] [PubMed]

75. Sundaresan, N.; Thomas, T.; Thomas, T.J.; Pillai, C.K.S. Investigations on the spermine provoked liquid crystalline phase behavior of high molecular weight DNA in the presence of alkali and alkaline earth metal ions. Polym. Chem. 2011, 2, 2835-2841. [CrossRef]

76. Bouxsein, N.F.; Leal, C.; McAllister, C.S.; Ewert, K.K.; Li, Y.; Samuel, C.E.; Safinya, C.R. Two-dimensional packing of short DNA with nonpairing overhangs in cationic liposome-DNA complexes: From Onsager nematics to columnar nematics with finite-length columns. J. Am. Chem. Soc. 2011, 133, 7585-7595. [CrossRef]

77. Garnacho, C. Intracellular drug delivery: Mechanisms for cell entry. Curr. Pharm. Des. 2016, 22, 1210-1226. [CrossRef]

78. Patel, S.; Kim, J.; Herrera, M.; Mukherjee, A.; Kabanov, A.V.; Sahay, G. Brief update on endocytosis of nanomedicines. Adv. Drug Deliv. Rev. 2019, 144, 90-111. [CrossRef]

79. Takei, K.; Haucke, V. Clathrin-mediated endocytosis: Membrane factors pull the trigger. Trends Cell Biol. 2001, 11, 385-391. [CrossRef]

80. Nichols, B. Caveosomes and endocytosis of lipid rafts. J. Cell Sci. 2003, 116, 4707-4714. [CrossRef]

81. Behzadi, S.; Serpooshan, V.; Tao, W.; Hamaly, M.A.; Alkawareek, M.Y.; Dreaden, E.C.; Mahmoudi, M. Cellular uptake of nanoparticles: Journey inside the cell. Chem. Soc. Rev. 2017, 46, 4218-4244. [CrossRef] [PubMed] 
82. Wollman, S.H. Turnover of plasma membrane in thyroid epithelium and review of evidence for the role of micropinocytosis. Eur. J. Cell Biol. 1989, 50, 247-256. [PubMed]

83. Von Gersdorff, K.; Sanders, N.N.; Vandenbroucke, R.; DeSmedt, S.C.; Wagner, E.; Ogris, M. The internalization route resulting in successful gene expression depends on both cell line and polyethylenimine polyplex type. Mol. Ther. 2006, 14, 745-753. [CrossRef] [PubMed]

84. Bhattacharjee, S. DLS and zeta potential-What they are and what they are not? J Control. Release 2016, 235, 337-351. [CrossRef]

85. Venkiteswaran, S.; Thomas, T.; Thomas, T.J. Selectivity of polyethyleneimines on DNA nanoparticle preparation and gene transport. ChemistrySelect 2016, 6, 1144-1150. [CrossRef]

86. Sun, X.; Ma, P.; Cao, X.; Ning, L.; Tian, Y.; Ren, C. Positive hyaluronan/PEI/DNA complexes as a target-specific intracellular delivery to malignant breast cancer. Drug Deliv. 2009, 16, 357-362. [CrossRef]

87. Park, J.; Singha, K.; Son, S.; Kim, J.; Namgung, R.; Yun, C.O.; Kim, W.J. A review of RGD-functionalized nonviral gene delivery vectors for cancer therapy. Cancer Gene Ther. 2012, 19, 741-748. [CrossRef]

88. Hu, J.; Sheng, Y.; Shi, J.; Yu, B.; Yu, Z.; Liao, G. Long circulating polymeric nanoparticles for gene/drug delivery. Curr. Drug Metab. 2018, 19, 723-738. [CrossRef]

89. Ge, Z.; Chen, Q.; Osada, K.; Liu, X.; Tockary, T.A.; Uchida, S.; Dirisala, A.; Ishii, T.; Nomoto, T.; Toh, K.; et al. Targeted gene delivery by polyplex micelles with crowded PEG palisade and cRGD moiety for systemic treatment of pancreatic tumors. Biomaterials 2014, 35, 3416-3426. [CrossRef]

90. Morris, V.B.; Neethu, S.; Abraham, T.E.; Pillai, C.K.S.; Sharma, C.P. Studies on the condensation of depolymerized chitosans with DNA for preparing chitosan-DNA nanoparticles for gene delivery applications. J. Biomed. Mater. Res. Part B Appl. Biomater. 2009, 89B, 282-292. [CrossRef]

91. Liu, Q.; Su, R.E.C.; Yi, W.J.; Zhao, Z.G. Biodegradable poly(amino ester) with aromatic backbone as efficient nonviral gene delivery vectors. Molecules 2017, 22, 566. [CrossRef] [PubMed]

92. Navarro, G.; Pan, J.; Torchilin, V.P. Micelle-like nanoparticles as carriers for DNA and siRNA. Mol. Pharm. 2015, 12, 301-313. [CrossRef] [PubMed]

93. Do, T.T.; Tang, V.J.; Aguilera, J.A.; Perry, C.C.; Milligan, J.R. Characterization of a lipophilic plasmid DNA condensate formed with a cationic peptide fatty acid conjugate. Biomacromolecules 2011, 12, 1731-1737. [CrossRef] [PubMed]

94. Zhou, T.; Llizo, A.; Wang, C.; Xu, G.; Yang, Y. Nanostructure-induced DNA condensation. Nanoscale 2013, 5, 8288-8306. [CrossRef]

95. Boussif, O.; Lezoualc'h, F.; Zanta, M.A.; Mergny, M.D.; Scherman, D.; Demeneix, B.; Behr, J.P. A versatile vector for gene and oligonucleotide transfer into cells in culture and in vivo: Polyethylenimine. Proc. Natl. Acad. Sci. USA 1995, 92, 7297-7301. [CrossRef]

96. Neuberg, P.; Kichler, A. Recent developments in nucleic acid delivery with polyethylenimines. Adv. Genet. 2014, 88, 263-288.

97. Hall, A.; Lächelt, U.; Bartek, J.; Wagner, E.; Moghimi, S.M. Polyplex evolution: Understanding biology, optimizing performance. Mol. Ther. 2017, 25, 1476-1490. [CrossRef]

98. Zhou, Y.; Yu, F.; Zhang, F.; Chen, G.; Wang, K.; Sun, M.; Li, J.; Oupický, D. Cyclam-modified PEI for combined VEGF siRNA silencing and CXCR4 inhibition to treat metastatic breast cancer. Biomacromolecules 2018, 19, 392-401. [CrossRef]

99. Nouri, F.; Sadeghpour, H.; Heidari, R.; Dehshahri, A. Preparation, characterization, and transfection efficiency of low molecular weight polyethylenimine-based nanoparticles for delivery of the plasmid encoding CD200 gene. Int. J. Nanomed. 2017, 12, 5557-5569. [CrossRef]

100. Choosakoonkriang, S.; Lobo, B.A.; Koe, G.S.; Koe, J.G.; Middaugh, C.R. Biophysical characterization of PEI/DNA complexes. J. Pharm. Sci. 2003, 92, 1710-1722. [CrossRef]

101. Godbey, W.T.; Wu, K.K.; Hirasaki, G.J.; Mikos, A.G. Improved packing of polyethylenimine/DNA complexes increases transfection efficiency. Gene Ther. 1999, 6, 1380-1388. [CrossRef] [PubMed]

102. Godbey, W.T.; Wu, K.K.; Mikos, A.G. Tracking the intracellular path of poly(ethylenimine)/DNA complexes for gene delivery. Proc. Natl. Acad. Sci. USA 1999, 96, 5177-5181. [CrossRef] [PubMed]

103. Lazarus, G.G.; Singh, M. In vitro cytotoxic activity and transfection efficiency of polyethyleneimine functionalized gold nanoparticles. Colloids Surf. B Biointerfaces 2016, 145, 906-911. [CrossRef] 
104. Zakeri, A.; Kouhbanani, M.A.J.; Beheshtkhoo, N.; Beigi, V.; Mousavi, S.M.; Hashemi, S.A.R.; Jahandideh, S. Polyethylenimine-based nanocarriers in co-delivery of drug and gene: A developing horizon. Nano Rev. Exp. 2018, 9, 1488497. [CrossRef] [PubMed]

105. Jiang, H.L.; Islam, M.A.; Xing, L.; Firdous, J.; Cao, W.; He, Y.J.; Zhu, Y.; Cho, K.H.; Li, H.S.; Cho, C.S. Degradable polyethylenimine-based gene carriers for cancer therapy. Top. Curr. Chem. 2017, 375, 34. [CrossRef] [PubMed]

106. Patnaik, S.; Gupta, K.C. Novel polyethylenimine-derived nanoparticles for in vivo gene delivery. Expert Opin. Drug Deliv. 2013, 10, 215-228. [CrossRef] [PubMed]

107. Lee, Y.; Mo, H.; Koo, H.; Park, J.Y.; Cho, M.Y.; Jin, G.W.; Park, J.S. Visualization of the degradation of a disulfide polymer, linear poly(ethylenimine sulfide), for gene delivery. Bioconjug. Chem. 2007, 18, 13-18. [CrossRef]

108. Gosselin, M.A.; Guo, W.; Lee, R.J. Efficient gene transfer using reversibly cross-linked low molecular weight polyethylenimine. Bioconjug. Chem. 2001, 12, 989-994. [CrossRef]

109. Liu, S.; Zhou, D.; Yang, J.; Zhou, H.; Chen, J.; Guo, T. Bioreducible Zinc(II)-coordinative polyethylenimine with low molecular weight for robust gene delivery of primary and stem cells. J. Am. Chem. Soc. 2017, 139, 5102-5109. [CrossRef]

110. Albuquerque, L.J.; Annes, K.; Milazzotto, M.P.; Mattei, B.; Riske, K.A.; Jäger, E.; De Freitas, A.G. Efficient condensation of DNA into environmentally responsive polyplexes produced from block catiomers carrying amine or diamine groups. Langmuir 2016, 32, 577-586. [CrossRef]

111. Gou, M.; Men, K.; Zhang, J.; Li, Y.; Song, J.; Luo, S.; Zhao, X. Efficient inhibition of C-26 colon carcinoma by VSVMP gene delivered by biodegradable cationic nanogel derived from polyethyleneimine. ACS Nano 2010, 4, 5573-5584. [CrossRef] [PubMed]

112. Wei, W.; Mu, Y.; Li, X.; Gou, M.; Zhang, H.; Luo, S.; Men, K.; Mao, Y.; Qian, Z.; Yang, L. Adenoviral vectors modified by heparin-polyethyleneimine nanogels enhance targeting to the lung and show therapeutic potential for pulmonary metastasis in vivo. J. Biomed. Nanotechnol. 2011, 7, 768-775. [CrossRef] [PubMed]

113. Bansal, R.; Gupta, K.C.; Kumar, P. Biodegradable and versatile polyethylenimine derivatives efficiently transfer DNA and siRNA into mammalian cells. Colloids Surf. B Biointerfaces 2015, 135, 661-668. [CrossRef] [PubMed]

114. Liu, L.; Zheng, M.; Librizzi, D.; Renette, T.; Merkel, O.M.; Kissel, T. Efficient and tumor targeted siRNA delivery by polyethylenimine-graft-polycaprolactone-block-poly(ethylene glycol)-folate (PEI-PCL-PEG-Fol). Mol. Pharm. 2016, 13, 134-143. [CrossRef] [PubMed]

115. Wang, W.; Balk, M.; Deng, Z.; Wischke, C.; Gossen, M.; Lendlein, A. Engineering biodegradable micelles of polyethylenimine-based amphiphilic block copolymers for efficient DNA and siRNA delivery. J. Control. Release 2016, 242, 71-79. [CrossRef]

116. Hu, J.; Zhu, M.; Liu, K.; Fan, H.; Zhao, W.; Mao, Y.; Zhang, Y. A biodegradable polyethylenimine-based vector modified by trifunctional peptide R18 for enhancing gene transfection efficiency in vivo. PLoS ONE 2016, 11, e0166673. [CrossRef]

117. Ruan, C.; Liu, L.; Wang, Q.; Chen, X.; Chen, Q.; Lu, Y.; Sun, T.; Jiang, C. Reactive oxygen species biodegradable gene carrier for the targeting therapy of breast cancer. ACS Appl. Mater. Interfaces 2018, 10, 10398-10408. [CrossRef]

118. Zhang, J.-H.; Yang, H.-Z.; Zhang, J.; Liu, Y.-H.; He, X.; Xiao, Y.-P.; Yu, X.Q. biodegradable gene carriers containing rigid aromatic linkage with enhanced dna binding and cell uptake. Polymers 2018, 10, 1080. [CrossRef]

119. Nam, J.P.; Nah, J.W. Target gene delivery from targeting ligand conjugated chitosan-PEI copolymer for cancer therapy. Carbohydr. Polym. 2016, 135, 153-161. [CrossRef]

120. Tripathi, S.K.; Goyal, R.; Kashyap, M.P.; Pant, A.B.; Haq, W.; Kumar, P.; Gupta, K.C. Depolymerized chitosans functionalized with bPEI as carriers of nucleic acids and tuftsin-tethered conjugate for macrophage targeting. Biomaterials 2012, 33, 4204-4219. [CrossRef]

121. Tseng, W.C.; Fang, T.Y.; Su, L.Y.; Tang, C.H. Dependence of transgene expression and the relative buffering capacity of dextran-grafted polyethylenimine. Mol. Pharm. 2005, 2, 224-232. [CrossRef] [PubMed]

122. Kanga, J.-H.; Tachibana, Y.; Kamata, W.; Mahara, A.; Harada-Shiba, M.; Yamaoka, T. Liver-targeted siRNA delivery by polyethylenimine (PEI)-pullulan carrier. Bioorg. Med. Chem. 2010, 18, 3946-3950. [CrossRef] [PubMed] 
123. Wang, J.; Dou, B.; Bao, Y. Efficient targeted pDNA/siRNA delivery with folate-low- molecular-weight polyethyleneimine-modified pullulan as non-viral carrier. Mater. Sci. Eng. C Mater. Biol. Appl. 2014, 34, 98-109. [CrossRef] [PubMed]

124. Chen, L.; Ji, F.; Bao, Y.; Xia, J.; Guo, L.; Wang, J.; Li, Y. Biocompatible cationic pullulan- $\gamma$-desoxycholic acid-g-PEI micelles used to co-deliver drug and gene for cancer therapy. Mater. Sci. Eng. C Mater. Biol. Appl. 2017, 70, 418-429. [CrossRef] [PubMed]

125. Hashemi, M.; Parhiz, B.; Hatefi, A.; Ramezani, M. Modified polyethyleneimine with histidine-lysine short peptides as gene carrier. Cancer Gene Ther. 2011, 18, 12-19. [CrossRef] [PubMed]

126. Parhiz, H.; Hashemi, M.; Hatefi, A.; Shier, W.T.; Amel Farzad, S.; Ramezani, M. Arginine-rich hydrophobic polyethylenimine: Potent agent with simple components for nucleic acid delivery. Int. J. Biol. Macromol. 2013, 60, 18-27. [CrossRef]

127. Nguyen, J.; Xie, X.; Neu, M.; Dumitrascu, R.; Reul, R.; Sitterberg, J.; Gessler, T. Effects of cell- penetrating peptides and pegylation on transfection efficiency of polyethylenimine in mouse lungs. J. Gene Med. 2008, 10, 1236-1246. [CrossRef]

128. Liu, Y.; Li, Y.; Keskin, D.; Shi, L. Poly( $\beta$-amino esters): Synthesis, formulations, and their biomedical applications. Adv. Healthc. Mater. 2019, 8, e1801359. [CrossRef]

129. Guerrero-Cázares, H.; Tzeng, S.Y.; Young, N.P.; Abutaleb, A.O.; Quiñones-Hinojosa, A.; Green, J.J. Biodegradable polymeric nanoparticles show high efficacy and specificity at DNA delivery to human glioblastoma in vitro and in vivo. ACS Nano 2014, 8, 5141-5153. [CrossRef]

130. Liu, M.; Chen, J.; Xue, Y.N.; Liu, W.M.; Zhuo, R.X.; Huang, S.W. Poly(beta-aminoester)s with pendant primary amines for efficient gene delivery. Bioconjug. Chem. 2009, 20, 2317-2323. [CrossRef]

131. Caffery, B.; Lee, J.S.; Alexander-Bryant, A.-A. Vectors for glioblastoma gene therapy: Viral \& non-viral delivery strategies. Nanomaterials 2019, 9, 105.

132. Sunshine, J.C.; Peng, D.Y.; Green, J.J. Uptake and transfection with polymeric nanoparticles are dependent on polymer end-group structure, but largely independent of nanoparticle physical and chemical properties. Mol. Pharm. 2012, 9, 3375-3383. [CrossRef] [PubMed]

133. Zhou, J.; Liu, J.; Cheng, C.J.; Patel, T.R.; Weller, C.E.; Piepmeier, J.M.; Saltzman, W.M. Biodegradable poly(amine-co-ester) terpolymers for targeted gene delivery. Nat. Mater. 2011, 11, 82-90. [CrossRef] [PubMed]

134. Keeney, M.; Ong, S.G.; Padilla, A.; Yao, Z.; Goodman, S.; Wu, J.C.; Yang, F. Development of poly( $\beta$-amino ester)-based biodegradable nanoparticles for nonviral delivery of minicircle DNA. ACS Nano 2013, 7, 7241-7750. [CrossRef] [PubMed]

135. Mastorakos, P.; da Silva, A.L.; Chisholm, J.; Song, E.; Choi, W.K.; Boyle, M.P.; Suk, J.S. Highly compacted biodegradable DNA nanoparticles capable of overcoming the mucus barrier for inhaled lung gene therapy. Proc. Natl. Acad. Sci. USA 2015, 112, 8720-8725. [CrossRef]

136. Fields, R.J.; Quijano, E.; McNeer, N.A.; Caputo, C.; Bahal, R.; Anandalingam, K.; Saltzman, W.M. Modified poly(lactic-co-glycolic acid) nanoparticles for enhanced cellular uptake and gene editing in the lung. Adv. Healthc. Mater. 2015, 4, 361-366. [CrossRef]

137. Mastorakos, P.; Zhang, C.; Song, E.; Kim, Y.E.; Park, H.W.; Berry, S.; Suk, J.S. Biodegradable brain-penetrating DNA nanocomplexes and their use to treat malignant brain tumors. J. Control Release 2017, 262, 37-46. [CrossRef]

138. Kauffman, A.C.; Piotrowski-Daspit, A.S.; Nakazawa, K.H.; Jiang, Y.; Datye, A.; Saltzman, W.M. Tunability of biodegradable poly(amine-co-ester) polymers for customized nucleic acid delivery and other biomedical applications. Biomacromolecules 2018, 19, 3861-3873. [CrossRef]

139. Wilson, D.R.; Rui, Y.; Siddiq, K.; Routkevitch, D.; Green, J.J. differentially branched ester amine quadpolymers with amphiphilic and $\mathrm{pH}$-sensitive properties for efficient plasmid DNA delivery. Mol. Pharm. 2019, 16, 655-668. [CrossRef]

140. Rui, Y.; Wilson, D.R.; Sanders, K.; Green, J.J. Reducible branched ester-amine quadpolymers (rBEAQs) codelivering plasmid DNA and RNA oligonucleotides enable CRISPR/cas9 genome editing. ACS Appl. Mater. Interfaces 2019, 11, 10472-10480. [CrossRef]

141. Shi, B.; Zheng, M.; Tao, W.; Chung, R.; Jin, D.; Ghaffari, D.; Farokhzad, O.C. Challenges in DNA Delivery and Recent Advances in Multifunctional Polymeric DNA Delivery Systems. Biomacromolecules 2017, 18, 2231-2246. [CrossRef] [PubMed] 
142. Korolev, N.; Berezhnoy, N.V.; Eom, K.D.; Tam, J.P.; Nordenskiöld, L.A. A universal description for the experimental behavior of salt-(in)dependent oligocation-induced DNA condensation. Nucleic Acids Res. 2012, 40, 2808-2821. [CrossRef] [PubMed]

143. Tian, H.; Lin, L.; Jiao, Z.; Guo, Z.; Chen, J.; Gao, S.; Zhu, X.; Chen, X. Polylysine-modified polyethylenimine inducing tumor apoptosis as an efficient gene carrier. J. Control Release 2013, 172, 410-418. [CrossRef] [PubMed]

144. Malik, Y.S.; Sheikh, M.A.; Xing, Z.; Guo, Z.; Zhu, X.; Tian, H.; Chen, X. Polylysine-modified polyethylenimine polymer can generate genetically engineered mesenchymal stem cells for combinational suicidal gene therapy in glioblastoma. Acta Biomater. 2018, 80, 144-153. [CrossRef] [PubMed]

145. Kodama, Y.; Nakamura, T.; Kurosaki, T.; Egashira, K.; Mine, T.; Nakagawa, H.; Sasaki, H. Biodegradable nanoparticles composed of dendrigraft poly-L-lysine for gene delivery. Eur. J. Pharm. Biopharm. 2014, 87, 472-479. [CrossRef]

146. Chen, B.; Yu, L.; Li, Z.; Wu, C. Design of free triblock polylysine- $b$-polyleucine- $b$-polylysine chains for gene delivery. Biomacromolecules 2018, 19, 1347-1357. [CrossRef]

147. Kalafatovic, D.; Giralt, E. Cell-penetrating peptides: Design strategies beyond primary. Structure and amphipathicity. Molecules 2017, 22, 1929. [CrossRef]

148. Jones, A.T.; Sayers, E.J. Cell entry of cell penetrating peptides: Tales of tails wagging dogs. J. Control Release 2012, 161, 582-591. [CrossRef]

149. Bjorge, J.D.; Pang, A.; Fujita, D.J. Delivery of gene targeting siRNAs to breast cancer cells using a multifunctional peptide complex that promotes both targeted delivery and endosomal release. PLoS ONE 2017, 12, e0180578. [CrossRef]

150. Elzoghby, A.O.; Abd-Elwakil, M.M.; Abd-Elsalam, K.; Elsayed, M.T.; Hashem, Y.; Mohamed, O. Natural polymeric nanoparticles for brain-targeting: Implications on drug and gene delivery. Curr. Pharm. Des. 2016, 22, 3305-3323. [CrossRef]

151. Fathi, M.; Majidi, S.; Zangabad, P.S.; Barar, J.; Erfan-Niya, H.; Omidi, Y. Chitosan-based multifunctional nanomedicines and theranostics for targeted therapy of cancer. Med. Res. Rev. 2018, 38, 2110-2136. [CrossRef] [PubMed]

152. Kumar, M.N.V.; Muzzarelli, R.A.A.; Muzzarelli, C.; Sashiwa, H.; Domb, A.J. Chitosan chemistry and pharmaceutical perspectives. Chem. Rev. 2004, 104, 6017-6084. [CrossRef] [PubMed]

153. Bhattarai, N.; Gunn, J.; Zhang, M.Q. Chitosan-based hydrogels for controlled, localized drug delivery. Adv. Drug Delivery Rev. 2010, 62, 83-99. [CrossRef] [PubMed]

154. Bravo-Anaya, L.M.; Soltero, J.F.; Rinaudo, M. DNA/chitosan electrostatic complex. Int. J. Biol. Macromol. 2016, 88, 345-353. [CrossRef] [PubMed]

155. Putnam, D. Polymers for gene delivery across length scales. Nat. Mater. 2006, 5, 439-451. [CrossRef] [PubMed]

156. Amaduzzi, F.; Bomboi, F.; Bonincontro, A.; Bordi, F.; Casciardi, S.; Chronopoulou, L.; Sennato, S. Chitosan-DNA complexes: Charge inversion and DNA condensation. Colloids Surf. B Biointerface 2014, 114, 1-10. [CrossRef] [PubMed]

157. Morris, V.B.; Pillai, C.K.S.; Sharma, C.P. Folic acid conjugated depolymerised quaternised chitosan as potential targeted gene delivery vector. Polym. Int. 2011, 60, 1097-1106. [CrossRef]

158. Zheng, Y.; Cai, Z.; Song, X.; Chen, Q.; Bi, Y.; Li, Y.; Hou, S. Preparation and characterization of folate conjugated N-trimethyl chitosan nanoparticles as protein carrier targeting folate receptor: In vitro studies. J. Drug Target. 2009, 17, 294-303. [CrossRef]

159. Morris, V.B.; Sharma, C.P. Folate mediated histidine derivative of quaternised chitosan as a gene delivery vector. Int. J. Pharm. 2010, 389, 176-185. [CrossRef]

160. Hakimi, S.; Mortazavian, E.; Mohammadi, Z.; Samadi, F.Y.; Samadikhah,H.; Taheritarigh, S.; Rafiee-Tehrani, M. Thiolated methylated dimethylaminobenzyl chitosan: A novel chitosan derivative as a potential delivery vehicle. Int. J. Biol. Macromol. 2017, 95, 574-581. [CrossRef]

161. Rahmani, S.; Hakimi, S.; Esmaeily, A.; Samadi, F.Y.; Mortazavian, E.; Nazari, M.; Tehrani, M.R. Novel chitosan based nanoparticles as gene delivery systems to cancerous and noncancerous cells. Int. J. Pharm. 2019, 560, 306-314. [CrossRef] [PubMed] 
162. Varkouhi, A.K.; Lammers, T.; Schiffelers, R.M.; van Steenbergen, M.J.; Hennink, W.E.; Storm, G. Gene silencing activity of siRNA polyplexes based on biodegradable polymers. Eur. J. Pharm. Biopharm. 2011, 77, 450-457. [CrossRef] [PubMed]

163. Taniuchi, K.; Yawata, T.; Tsuboi, M.; Ueba, T.; Saibara, T. Efficient delivery of small interfering RNAs targeting particular mRNAs into pancreatic cancer cells inhibits invasiveness and metastasis of pancreatic tumors. Oncotarget 2019, 10, 2869-2886. [CrossRef] [PubMed]

164. Capel, V.; Vllasaliu, D.; Watts, P.; Clarke, P.A.; Luxton, D.; Grabowska, A.M.; Stolnik, S. Water-soluble substituted chitosan derivatives as technology platform for inhalation delivery of siRNA. Drug Deliv. 2018, 25, 644-653. [CrossRef]

165. Dowaidar, M.; Nasser Abdelhamid, H.; Hällbrink, M.; Langel, Ü.; Zou, X. Chitosan enhances gene delivery of oligonucleotide complexes with magnetic nanoparticles-cell-penetrating peptide. J. Biomater. Appl. 2018, 33, 392-401. [CrossRef]

166. Zhang, H.; Bahamondez-Canas, T.F.; Zhang, Y.; Leal, J.; Smyth, H.D.C. Pegylated chitosan for nonviral aerosol and mucosal delivery of the crispr/cas9 system in vitro. Mol. Pharm. 2018, 15, 4814-4826. [CrossRef]

167. Sanchez-Ramos, J.; Song, S.; Kong, X.; Foroutan, P.; Martinez, G.; Dominguez-Viqueria, W.; Aronin, N.; Sava, V. Chitosan-mangafodipir nanoparticles designed for intranasal delivery of siRNA and DNA to brain. J. Drug Deliv. Sci. Technol. 2018, 43, 453-460. [CrossRef]

168. Tabasum, S.; Noreen, A.; Maqsood, M.F.; Umar, H.; Akrama, N.; Nazli, Z.H.; Chatha, S.A.S.; Zia, K.M. A review on versatile applications of blends and composites of pullulan with natural and synthetic polymers. Int. J. Biol. Macromol. 2018, 120, 603-632. [CrossRef]

169. Singh, R.S.; Kaur, N.; Kennedy, J.F. Pullulan and pullulan derivatives as promising biomolecules for drug and gene targeting. Carbohydr. Polym. 2015, 123, 190-207. [CrossRef]

170. Hosseinkhani, H.; Aoyama, T.; Ogawa, O.; Tabata, Y. Liver targeting of plasmid DNA by pullulan conjugation based on metal coordination. J. Control Release 2002, 83, 287-302. [CrossRef]

171. Priya, S.S.; Rekha, M.R.; Sharma, C.P. Pullulan-protamine as efficient haemocompatible gene delivery vector: Synthesis and in vitro characterization. Carbohydr. Polym. 2014, 102, 207-215. [CrossRef] [PubMed]

172. Zhang, S.; Wang, D.; Li, Y.; Li, L.; Chen, H.; Xiong, Q.; Liu, Y.; Wang, Y.pH- and redox-responsive nanoparticles composed of charge-reversible pullulan-based shells and disulfide-containing poly(ß-amino ester) cores for co-delivery of a gene and chemotherapeutic agent. Nanotechnology 2018, 29, 325101. [CrossRef] [PubMed]

173. Askarian, S.; Abnous, K.; Ayatollahi, S.; Farzad, S.A.; Oskuee, R.K.; Ramezani, M. PAMAM- pullulan conjugates as targeted gene carriers for liver cell. Carbohydr. Polym. 2017, 157, 929-937. [CrossRef] [PubMed]

174. Raemdonck, K.; Martens, T.F.; Braeckmans, K.; Demeester, J.; De Smedt, S.C. Polysaccharide- based nucleic acid nanoformulations. Adv. Drug Deliv. Rev. 2013, 65, 1123-1147. [CrossRef] [PubMed]

175. Raemdonck, K.; Naeye, B.; Buyens, K.; Vandenbroucke, R.E.; Hogset, A.; Demeester, J.; De Smedt, S.C. Biodegradable dextran nanogels for RNA interference: Focusing on endosomal escape and intracellular siRNA delivery. Adv. Funct. Mater. 2009, 19, 1406-1415. [CrossRef]

176. Cho, H.J.; Chong, S.; Chung, S.J.; Shim, C.K.; Kim, D.D. Poly-L-arginine and dextran sulfate-based nanocomplex for epidermal growth factor receptor (EGFR) siRNA delivery: Its application for head and neck cancer treatment. Pharm. Res. 2012, 29, 1007-1019. [CrossRef]

177. Tseng, W.C.; Jong, C.M. Improved stability of polycationic vector by dextran-grafted branched polyethylenimine. Biomacromolecules 2003, 4, 1277-1284. [CrossRef]

178. Jiang, D.; Salem, A.K. Optimized dextran-polyethylenimine conjugates are efficient non-viral vectors with reduced cytotoxicity when used in serum containing environments. Int. J. Pharm. 2012, 427, 71-79. [CrossRef]

179. Nimesh, S.; Kumar, R.; Chandra, R. Novel polyallylamine-dextran sulfate-DNA nanoplexes: Highly efficient non-viral vector for gene delivery. Int. J. Pharm. 2006, 320, 143-149. [CrossRef]

180. Perumal, V.; Arfuso, F.; Chen, Y.; Fox, S.; Dharmarajan, A.M. Delivery of expression constructs of secreted frizzled-related protein 4 and its domains by chitosan-dextran sulfate nanoparticles enhances their expression and anti-cancer effects. Mol. Cell Biochem. 2018, 443, 205-213. [CrossRef]

181. Hu, Y.; Wang, H.; Song, H.; Young, M.; Fan, Y.; Xu, F.J.; Cheng, G. Peptide-grafted dextran vectors for efficient and high-loading gene delivery. Biomater. Sci. 2019, 7, 1543-1553. [CrossRef] [PubMed]

182. Arpicco, S.; Milla, P.; Stella, B.; Dosio, F. Hyaluronic acid conjugates as vectors for the active targeting of drugs, genes and nanocomposites in cancer treatment. Molecules 2014, 19, 3193-3230. [CrossRef] [PubMed] 
183. Oyarzun-Ampuero, F.A.; Goycoolea, F.M.; Torres, D.; Alonso, M.J. A new drug nanocarrier consisting of polyarginine and hyaluronic acid. Eur. J. Pharm. Biopharm. 2011, 79, 54-57. [CrossRef] [PubMed]

184. Paidikondala, M.; Rangasami, V.K.; Nawale, G.N.; Casalini, T.; Perale, G.; Kadekar, S.; Mohanty, G.; Salminen, T.; Oommen, O.P.; Varghese, O.P. An unexpected role of hyaluronic acid in trafficking siRNA across the cellular barrier: The first biomimetic, anionic, non-viral transfection method. Angew. Chem. Int. Ed. Engl. 2019, 58, 2815-2819. [CrossRef] [PubMed]

185. Aldawsari, H.M.; Dhaliwal, H.K.; Aljaeid, B.M.; Alhakamy, N.A.; Banjar, Z.M.; Amiji, M.M. Optimization of the conditions for plasmid DNA delivery and transfection with self-assembled hyaluronic acid-based nanoparticles. Mol. Pharm. 2019, 11, 128-140. [CrossRef] [PubMed]

186. Kim, E.J.; Cho, H.J.; Park, D.; Kim, J.Y.; Kim, Y.B.; Park, T.G.; Oh, Y.K. Antifibrotic effect of MMP13-encoding plasmid DNA delivered using polyethylenimine shielded with hyaluronic acid. Mol. Ther. 2011, 19, 355-361. [CrossRef]

187. Holmes, C.A.; Tabrizian, M. Substrate-mediated gene delivery from glycol-chitosan/hyaluronic acid polyelectrolyte multilayer films. ACS Appl. Mater. Interfaces 2013, 5, 524-531. [CrossRef]

188. Tirella, A.; Kloc-Muniak, K.; Good, L.; Ridden, J.; Ashford, M.; Puri, S.; Tirelli, N. CD44 targeted delivery of siRNA by using HA-decorated nanotechnologies for KRAS silencing in cancer treatment. Int. J. Pharm. 2019, 561, 114-123. [CrossRef]

189. Koenig, O.; Neumann, B.; Schlensak, C.; Wendel, H.P.; Nolte, A. Hyaluronic acid/poly(ethylenimine) polyelectrolyte multilayer coatings for siRNA-mediated local gene silencing. PLoS ONE 2019, 14, e0212584. [CrossRef]

(C) 2019 by the authors. Licensee MDPI, Basel, Switzerland. This article is an open access article distributed under the terms and conditions of the Creative Commons Attribution (CC BY) license (http://creativecommons.org/licenses/by/4.0/). 